\title{
Total Synthesis of Desmethyl Jahanyne and Its Lipo-Tetrapeptide Conjugates Derived from Parent Skeleton as BCL-2-Mediated Apoptosis-Inducing Agents
}

\author{
Shivakrishna Kallepu, ${ }^{\dagger, \perp}$ Minnapuram Kavitha, ${ }^{\dagger, \|, \perp}$ Ragini Yeeravalli, ${ }^{\ddagger, \|}$ Kanakaraju Manupati, ${ }^{\ddagger}, \|$
} Surender Singh Jadav, ${ }^{\dagger}$ Amitava Das, ${ }^{\ddagger}, \|_{\odot}$ Prathama S. Mainkar, ${ }^{\S}, \|$ and Srivari Chandrasekhar ${ }^{*}, \dagger, \|_{\odot}$

${ }^{\dagger}$ Natural Products Chemistry Division, ${ }^{\ddagger}$ Centre for Chemical Biology, and ${ }^{\S}$ Medicinal Chemistry \& Biotechnology, CSIR-Indian Institute of Chemical Technology (CSIR-IICT), Hyderabad 500007, India

"Academy of Scientific and Innovative Research (AcSIR), New Delhi 110020, India

Supporting Information
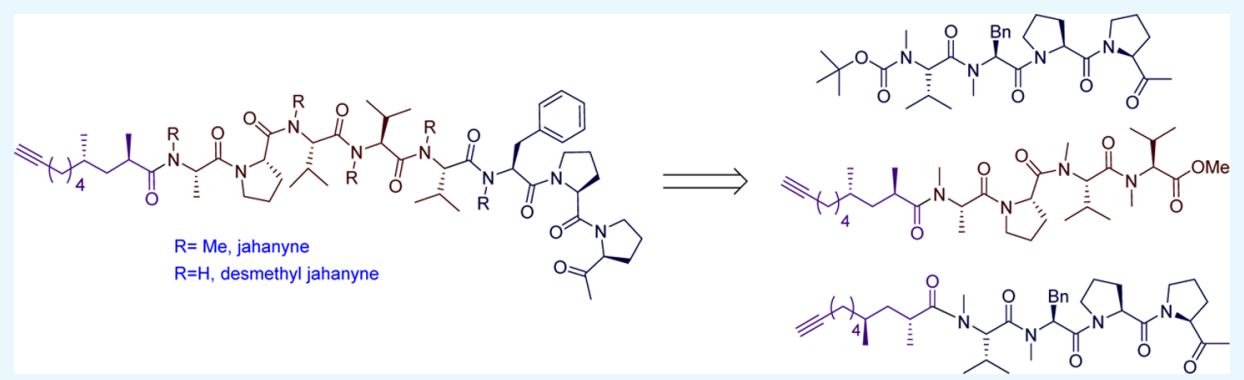

ABSTRACT: The total synthesis of highly potent and scarcely available marine natural product (-)-jahanyne was attempted resulting in a solution-phase synthesis of pruned versions with comparable activity. A simple and facile synthetic route was employed for the preparation of pruned congeners and would be scalable. The lipophilic tail of the natural product was synthesized from $R-(+)$-citronellol, utilizing easily available chemicals. All the synthesized compounds were screened for apoptotic activity against a panel of cell lines. These compounds depicted marked binding to B cell lymphoma 2 till $50{ }^{\circ} \mathrm{C}$ in cellular thermal shift analysis.

\section{INTRODUCTION}

Marine cyanobacteria have been an excellent source of new natural products with unique biological profiles. ${ }^{1,2}$ Suenaga et al. $^{3-6}$ have investigated the constituents of marine cyanobacterium, Lyngbya sp., and isolated an acetylene-containing lipopeptide, jahanyne (1). This marine natural product has a rare lipophilic tail (chiral 2,4-dimethyl decynoic acid 2) and an uncommon hydrophilic head engaging per $\mathrm{N}$-methylated octamer [including Oep (2-(1-oxo-ethyl)-pyrrolidine moiety)]. The $\mathrm{N}$-terminal decynoic acid moiety 2 is reported to be a part structure only once before in carmabin $A, 7,8$ whose absolute stereochemistry is not reported yet. Jahanyne (1) has shown promising growth inhibition of human cancer cells and induced apoptosis in HeLa cells $(1.8 \mu \mathrm{M})$. Cell suicide is an important process of all living organisms where unwanted cells are removed from the body. For a healthy being, a balance between cell death and proliferation has to be maintained. The genetic studies on Caenorhabditis elegans and its correlation to human genes have helped to identify a previously unknown gene BCL2 (B cell lymphoma 2) from the breakpoint region of a recurrent chromosomal translocation in human follicular lymphoma. Enforced overexpression of BCL-2 promoted lymphocyte accumulation in mice studies which resulted either in autoimmune diseases or in cancer. ${ }^{9,10}$
The fascinating biological activity and bolaamphiphile mimicking skeleton feature of jahanyne attracted our attention to take up the total synthesis. Incidentally no total synthesis is reported yet. Herein, we report our attempts toward the total synthesis of jahanyne, where the efforts culminated in the synthesis of desmethyl jahanyne 1a and few pruned analogues 28 and 29. Interestingly, one of these pruned versions had comparable activity with respect to natural product. Disappointingly, the permethylation efforts of converting 1a to 1 were futile. Our efforts also provided lead toward pruning large molecular weight natural products to low-molecular-weight analogues with comparable biological profile.

Retrosynthetically, 1a could be envisioned to be synthesized by coupling of lipophilic acid $\mathbf{2}$ with the desmethyl octapeptide 3a. This would be a prerequisite advanced scaffold for permethylation. Alternatively, permethylated octapeptide 3 could be directly coupled to 2 to achieve total synthesis of $\mathbf{1}$. The decynoic acid $\mathbf{2}$ was envisioned to synthesize from $R$ (+)-citronellol (which embodies one of the two chiral centers) via Evans' chemistry to install the second chiral center.

Received: October 25, 2017

Accepted: December 21, 2017

Published: January 4, 2018 


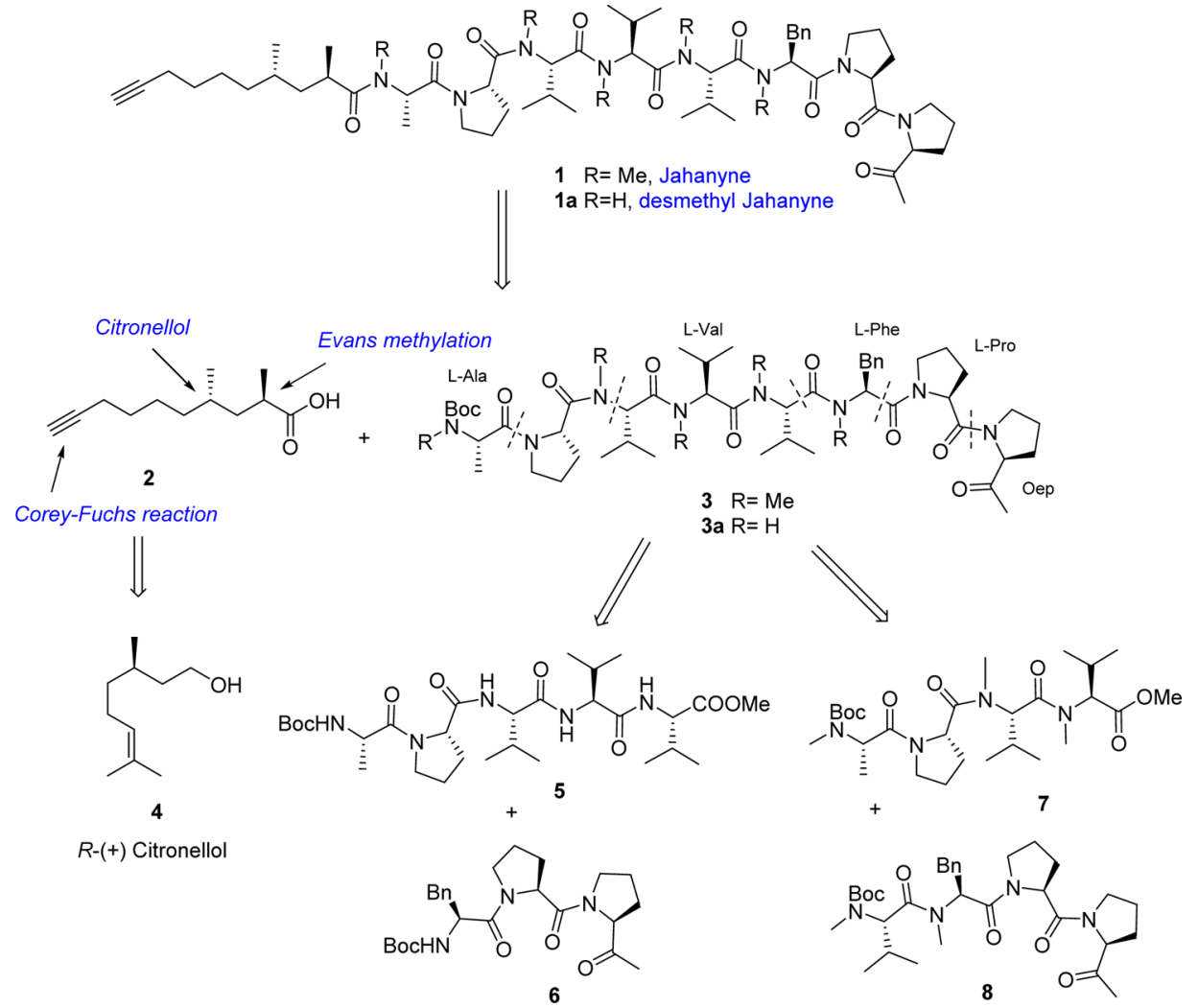

Figure 1. Retrosynthetic analysis.

\section{Scheme 1. Synthesis of Acid Fragment 2}
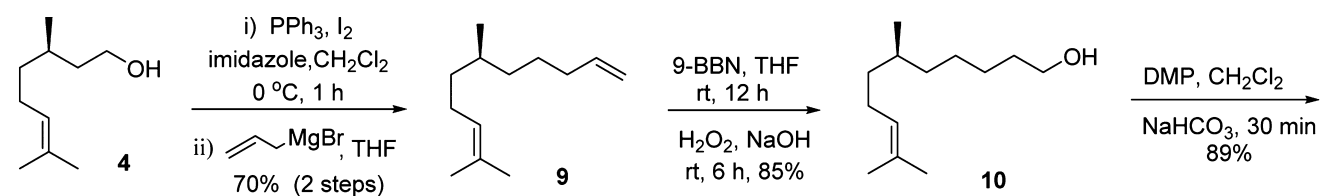

$R-(+)$ Citronellol
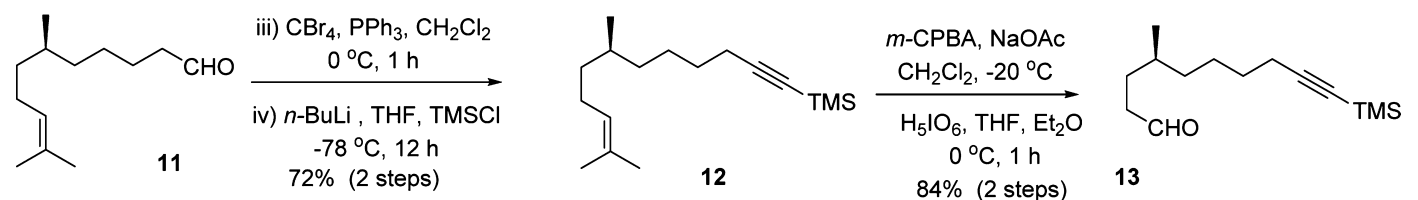

$84 \%$ (2 steps)

13
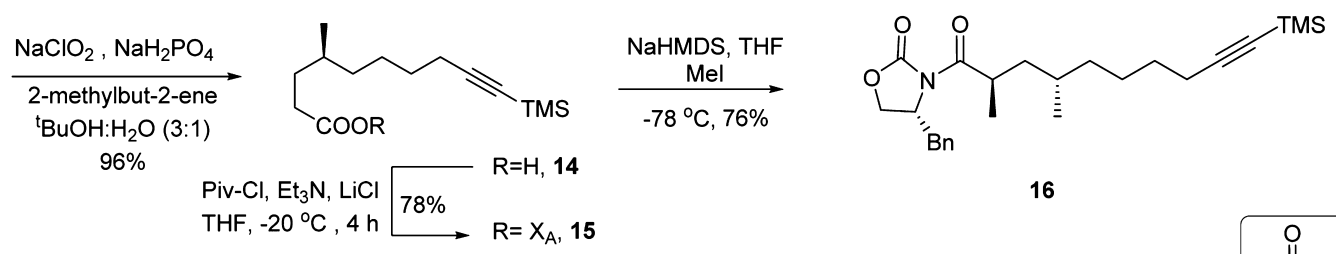

16
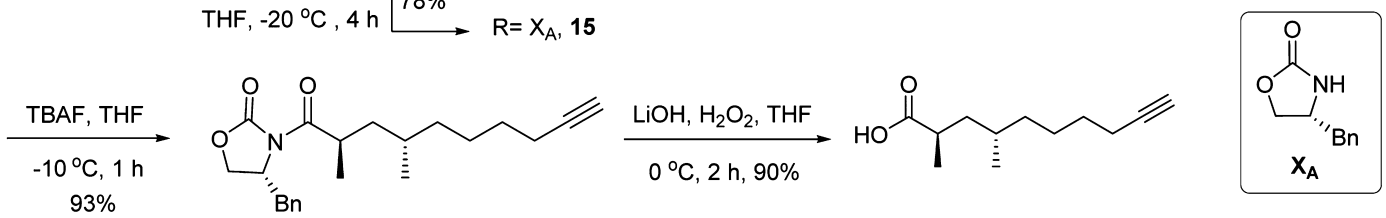

17

2

Similarly, the desmethyl octapeptide 3a was planned through 5mer +3 -mer approach by stitching desmethyl pentamer $\mathbf{5}$ and desmethyl trimer 6. Alternatively, the permethylated octapeptide 3 was planned to be synthesized by coupling permethylated tetramers 7 and 8 (Figure 1).

\section{RESULTS AND DISCUSSION}

$R$-(+)-Citronellol (4) was converted to diene 9 following the literature procedure. ${ }^{11}$ Hydroboration-oxidation sequence of 9 with 9-BBN and $\mathrm{H}_{2} \mathrm{O}_{2} / \mathrm{NaOH}$ gave alcohol 10 in $85 \%$ yield, ${ }^{12}$ which on oxidation with Dess-Martin periodinane (DMP) afforded aldehyde 11 in $89 \%$ yield. ${ }^{13}$ The Corey-Fuchs 
Scheme 2. Synthesis of Permethyl Tetramers 7 and $8^{a}$

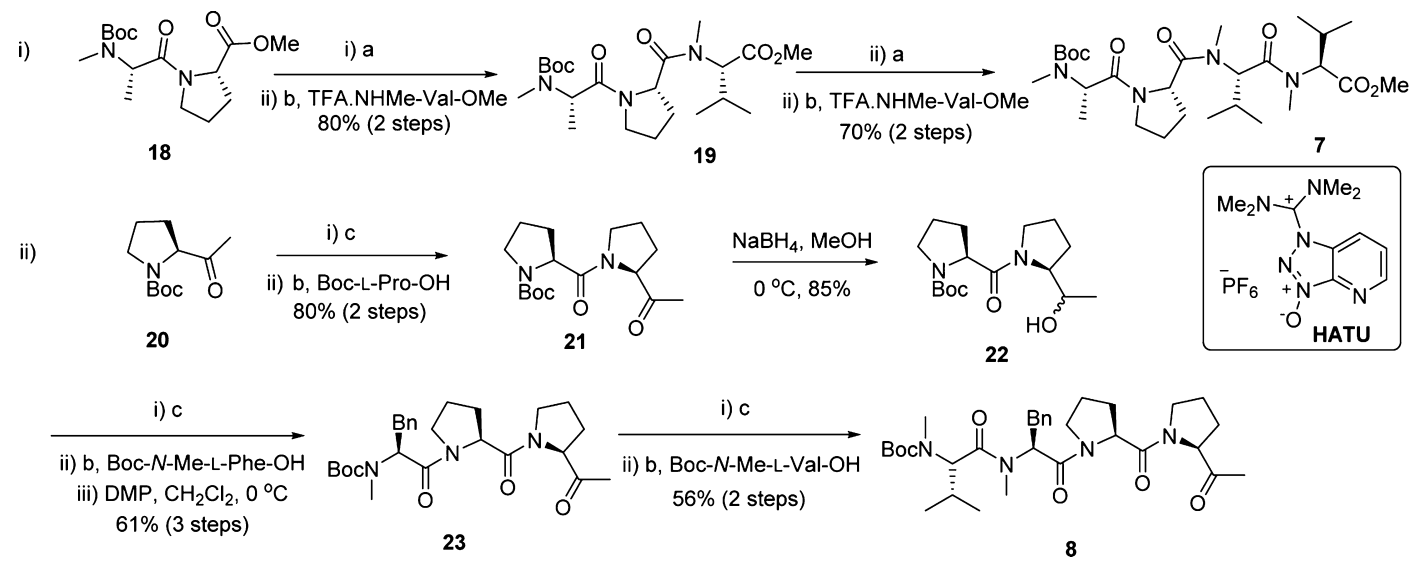

${ }^{a}$ Reagents and conditions: (a) $\mathrm{LiOH}, \mathrm{MeOH} / \mathrm{H}_{2} \mathrm{O}$; (b) HATU, DIPEA, DMF, $12 \mathrm{~h}$; and (c) TFA, $\mathrm{CH}_{2} \mathrm{Cl}_{2}, 2 \mathrm{~h}$.

Scheme 3. Synthesis of Desmethyl Jahanyne ${ }^{a}$<smiles>O=C(NC(Cc1ccccc1)C(=O)N1CCCC1C(=O)O)c1ccccc1</smiles>

24<smiles>CC(=O)OC(=O)NC(C(=O)NC(=O)c1ccccc1)C(C)C</smiles>

25

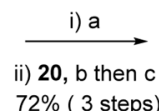

$72 \%$ ( 3 steps)

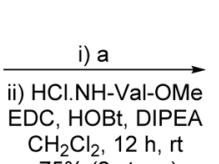

$\mathrm{CH}_{2} \mathrm{Cl}_{2}, 12 \mathrm{~h}, \mathrm{r}$

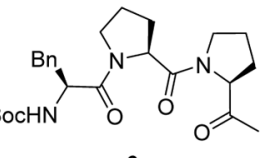

6<smiles>CC(=O)OC(C)(C)C(NC(=O)[C@H](NC(=O)[C@H](NC(=O)OCc1ccccc1)C(C)C)C(C)C)C(C)C</smiles>

26

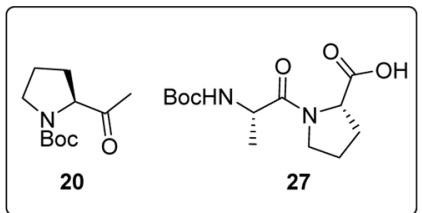

i) $b$
ii) 27,

ii) $27, c$
$64 \%$ ( 2 steps $)$<smiles>CC(=O)c1ccccc1</smiles>

$3 a$<smiles>C#CCCCC[C@H](C)C[C@H](C)C(=O)N[C@@H](C)C(=O)N1CC[C@@H]2C(C)[C@H](C(=O)N[C@H](C(=O)N[C@H](C(=O)NC(Cc3ccccc3)C(=O)N3CCC[C@H]3C(=O)N3CCC[C@H]3C(C)=O)C(C)C)C(C)C)C(=O)N21</smiles>

desmethyl jahanyne

1a

${ }^{a}$ Reagents and conditions: (a) $\mathrm{LiOH}, \mathrm{MeOH} / \mathrm{H}_{2} \mathrm{O}, 4 \mathrm{~h}$; (b) TFA, $\mathrm{CH}_{2} \mathrm{Cl}_{2}, 2$ h; and (c) HATU, DIPEA, DMF, rt, 12 h.

reaction with $\mathrm{CBr}_{4}$ and $n$-BuLi followed by the addition of trimethylsilyl chloride yielded the homologated tetramethylsilane (TMS)-alkyne 12 in $72 \%$ yield. ${ }^{14}$ The isopropylene group in 12 was cleaved using a two-step process, ${ }^{15,16}$ epoxidation with meta-chloroperoxybenzoic acid ( $m$-CPBA) followed by the addition of $\mathrm{H}_{5} \mathrm{IO}_{6}$ to furnish aldehyde 13 , which on oxidation with $\mathrm{NaClO}_{2}$ yielded the acid 14 .

The Evans' auxiliary $\left(\mathrm{X}_{\mathrm{A}}\right)$ was conjugated to acid 14 to furnish imide 15 in $78 \%$ yield. Methylation was accomplished using NaHMDS/MeI to provide 16 in $76 \%$ yield with $86 \%$ de. A column chromatographic separation allowed isolation of pure 16. ${ }^{17}$ Exposure of $\mathbf{1 6}$ to tetra- $n$-butylammonium fluoride (TBAF) allowed the cleavage of TMS in acetylenic functionality to generate free alkyne 17 in 93\% yield, which upon hydrolysis with $\mathrm{LiOH} / \mathrm{H}_{2} \mathrm{O}_{2}$ provided the acid unit $\mathbf{2}$ of jahanyne in $90 \%$ yield. $^{18}$ The executed route (Scheme 1) allowed us to synthesize gram quantities of lipophilic end of jahanyne toward total synthesis.

The octapeptide unit, for operational simplicity, was divided into two tetramers 7 and 8 . The $\mathrm{N}$-terminal unit 7 was synthesized in a stepwise manner by the addition of desired amino acids in protected form. Thus, the known dimer $18^{19}$ on hydrolysis of ester with lithium hydroxide and coupling with $\mathrm{N}$ Me-L-Val-OMe by following HATU and N,N-diisopropylethylamine (DIPEA) conditions yielded the trimer 19 in $80 \%$ over two steps. The hydrolysis of ester 19 with $\mathrm{LiOH}$ followed by coupling with $\mathrm{N}$-Me-L-Val-OMe following the same conditions furnished permethyl tetramer 7 .

The other permethyl tetramer $\mathbf{8}$ was synthesized by coupling the known Boc Oep $\mathbf{2 0}^{20}$ with N-Boc-L-Pro following HATUassisted amidation. The Boc group in 21 was removed with trifluoroacetic acid (TFA); however, the free $\mathrm{NH}$ group of 
Scheme 4. Synthesis of Fatty Acid Conjugates 28 and $29^{a}$<smiles>C#CCCCC[C@H](C)C[C@H](C)C(=O)O</smiles>

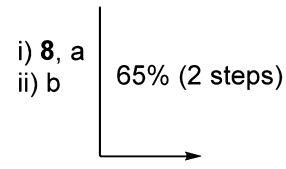

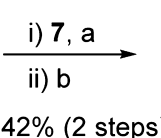

$42 \%$ (2 steps)<smiles>C#CCCCCC(C)C[C@@H](C)C(=O)N(C)[C@H](C(=O)N(C)C(Cc1ccccc1)C(=O)N1CCC[C@H]1C(=O)N1CCC[C@H]1C(C)=O)C(C)C</smiles>

29

${ }^{a}$ Reagents and conditions: (a) TFA, $\mathrm{CH}_{2} \mathrm{Cl}_{2}, 2 \mathrm{~h}$ and (b) HATU, DMF, DIPEA, rt, $12 \mathrm{~h}$.

Table 1. $\mathrm{IC}_{50}(\mu \mathrm{M})$ Values of Synthetic Analogues of Jahanyne ${ }^{a}$

\begin{tabular}{|c|c|c|c|c|c|c|}
\hline s. no. & compound no. & $M D A-M B-231$ & DU-145 & $A 549$ & $\mathrm{HeLa}$ & HEK-293 \\
\hline 1 & 18 & $11 \pm 2$ & $8 \pm 0.2$ & $28 \pm 4$ & $60 \pm 16$ & $2453 \pm 204$ \\
\hline 2 & 19 & $39 \pm 5$ & $3 \pm 0.2$ & $6 \pm 2$ & $22 \pm 3$ & $1208 \pm 44$ \\
\hline 3 & 7 & $56 \pm 3$ & $3 \pm 0.1$ & $3 \pm 0.2$ & $23 \pm 1$ & $369 \pm 25$ \\
\hline 5 & 28 & $3 \pm 0.7$ & $1 \pm 0.6$ & $1 \pm 0.3$ & $3 \pm 0.2$ & $97 \pm 17$ \\
\hline 6 & 17 & $102 \pm 14$ & $188 \pm 29$ & $158 \pm 15$ & $160 \pm 10$ & $293 \pm 16$ \\
\hline 7 & 2 & $164 \pm 20$ & $123 \pm 20$ & $167 \pm 12$ & $122 \pm 14$ & $259 \pm 35$ \\
\hline 9 & 22 & $8 \pm 0.4$ & $2 \pm 0.8$ & $0.5 \pm 0.03$ & $26 \pm 3$ & $3387 \pm 123$ \\
\hline 10 & 23 & $6 \pm 1$ & $1 \pm 0.9$ & $2 \pm 0.2$ & $9 \pm 1$ & $160 \pm 16$ \\
\hline 11 & 8 & $1 \pm 0.3$ & $1 \pm 0.7$ & $0.2 \pm 0.01$ & $1.6 \pm 0.1$ & $198 \pm 41$ \\
\hline 12 & 29 & $1 \pm 0.1$ & $1 \pm 0.7$ & $0.2 \pm 0.01$ & $3 \pm 1$ & $5762 \pm 51$ \\
\hline 14 & 25 & $7 \pm 0.7$ & $5 \pm 1$ & $1 \pm 0.3$ & $7 \pm 1$ & $238 \pm 34$ \\
\hline 15 & 26 & $30 \pm 1$ & $17 \pm 1$ & $1 \pm 0.3$ & $14 \pm 1$ & $145 \pm 19$ \\
\hline 16 & 24 & $16 \pm 2$ & $13 \pm 2$ & $6 \pm 0.4$ & $12 \pm 1$ & $238 \pm 34$ \\
\hline 18 & 5 & $33 \pm 0.4$ & $21 \pm 2$ & $1 \pm 0.1$ & $4 \pm 0.3$ & $412 \pm 65$ \\
\hline 19 & $3 a$ & $9 \pm 0.1$ & $1 \pm 0.1$ & $2 \pm 0.1$ & $12 \pm 11$ & $362 \pm 33$ \\
\hline 20 & $1 \mathrm{a}$ & $7 \pm 0.1$ & $1 \pm 0.1$ & $2 \pm 0.1$ & $39 \pm 1$ & $328 \pm 23$ \\
\hline 21 & doxorubicin & $1 \pm 0.1$ & $0.5 \pm 0.2$ & $1 \pm 0.1$ & $1 \pm 0.2$ & $39 \pm 2$ \\
\hline 22 & jahanyne $^{b}$ & & & & 1.8 & \\
\hline
\end{tabular}

${ }^{a}$ Human breast adenocarcinoma cell line-MDA-MB-231, prostate- $D U-145$, lung-A549, cervical-HeLa, and primary human embryonic kidney cell lineHEK-293 depicted as mean \pm SEM. ${ }^{b}$ Reported literature values. (For raw data, see Supporting Information Table S1).

proline ring participated in an intramolecular cyclization with keto group of Oep. ${ }^{4}$ To circumvent, compound 21 was reduced with $\mathrm{NaBH}_{4}$ to generate diastereomeric alcohol 22. Compound 22 was coupled with $\mathrm{N}$-Boc- $\mathrm{N}$-Me-L-Phe-OH after removing the Boc group in 22 with TFA, oxidation with DMP provided 23 in $61 \%$ yield. The resultant 23 on Boc-deprotection followed by coupling with $\mathrm{N}$-Boc-N-Me-L-Val-OH yielded permethyl tetramer 8 in $56 \%$ yield (Scheme 2).

With both permethylated tetramers in hand, we tried coupling of them to get the octapeptide 3. N-Boc deprotection of $\mathbf{8}$ and ester hydrolysis of $\mathbf{7}$ gave the corresponding amine and acid. However, coupling reagents such as HATU, COMU, PyBrop, and so forth did not yield the required octapeptide 3. In addition, coupling between acid chloride of 7 and free amine of $\mathbf{8}$ was also unsuccessful. At this point, we revisited our strategy and planned synthesis of desmethyl octapeptide 3a, which on coupling with 2 followed by permethylation would result in $\mathbf{1}$.

The synthesis of octapeptide $\mathbf{3 a}$ was planned from the coupling of pentamer 5 and trimer 3 . The dimer $24^{21}$ was subjected to saponification to get free acid, which was coupled with Oep to get trimer 6 in $72 \%$ yield (Scheme 3 ). The dimer $\mathbf{2 5}^{22}$ on ester hydrolysis with $\mathrm{LiOH}$ followed by coupling with valine methyl ester under EDC, hydroxybenzotriazole ( $\mathrm{HOBt}$ ) conditions gave the trimer 26 in $75 \%$ yield. TFA-catalyzed $N$ Boc hydrolysis of $\mathbf{2 6}$ followed by HATU-mediated peptide coupling with dimer 27 resulted in pentamer 5 in $64 \%$ yield over two steps. Ester hydrolysis of pentamer 5 with $\mathrm{LiOH}$ and coupling with $N$-Boc deprotected tripeptide 6 resulted in desmethyl octapeptide 3a. Exhaustive permethylation of $3 \mathrm{a}$ to 3 was futile under $\mathrm{NaH} / \mathrm{MeI}, \mathrm{Ag}_{2} \mathrm{O} / \mathrm{MeI},{ }^{23}\left(\mathrm{CH}_{3}\right)_{2} \mathrm{SO}_{4} / \mathrm{NaH},{ }^{24}$ dimethyl carbonate/cetrimonium bromide (CTAB), ${ }^{25}$ and HCOOMe/CTAB conditions. ${ }^{26}$ Condensation of deprotected amine group of $3 a$ with lipophilic acid 2 gave desmethyl jahanyne 1a in $44 \%$ yield over two steps.

Similarly, our efforts toward the synthesis of $\mathbf{1}$ from 1a through permethylation were also unsuccessful after several attempts. To explore any of the synthesized intermediates exhibit desired properties, we coupled the peptide units with the acid 2. Thus, we coupled the permethylated tetramer 7 and 

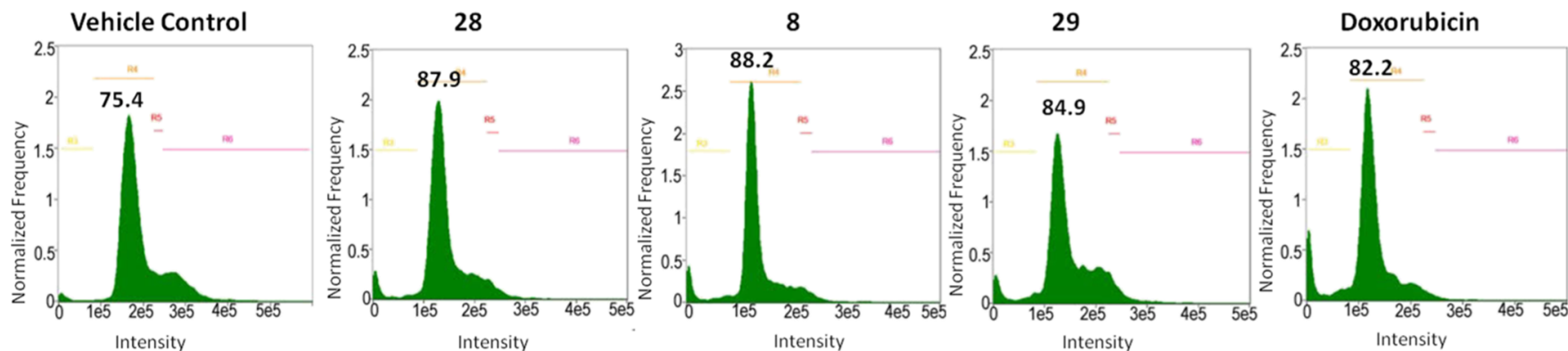

Figure 2. Cell cycle analysis in DU-145 cells treated with compounds $\mathbf{8}, \mathbf{2 8}$, and 29 depicted a $G_{0} / G_{1}$ cell cycle arrest. Doxorubicin was used as a positive control and depicted comparable effect.

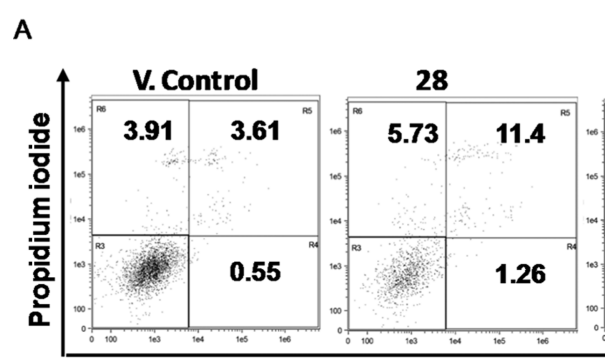

FACS

B

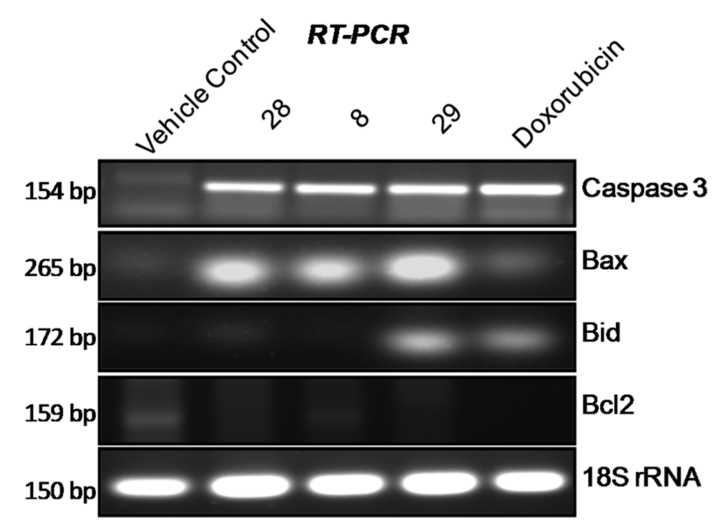

8
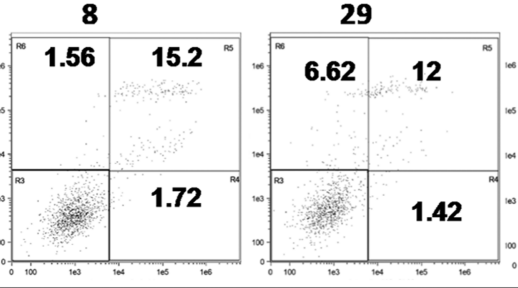

Doxorubicin

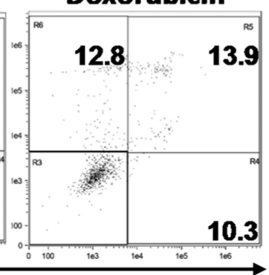

10.3

Annexin FITC

C

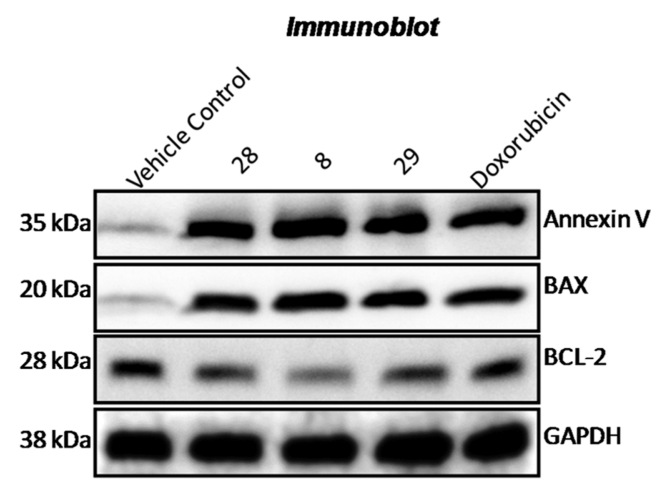

Figure 3. Cellular apoptosis in DU-145 cells treated with compounds 8, 28, and 29. (A) Increased percent of cells observed in the late apoptotic phase in the compound-treated group as compared to control. (B) RT-PCR analysis depicted an increased expression of proapoptotic genes Caspase 3 , Bax and Bid and concomitant decrease in antiapoptotic gene, Bcl-2. (C) Representative image of immunoblot analysis confirmed the gene expression in these cells at protein expression levels with an increase in proapoptotic proteins BAX, as well as Annexin V.

8 with 2 individually and isolated the conjugates $28^{27}$ and 29 in 42 and $65 \%$ yield, respectively, as pruned versions of the natural product (Scheme 4).

At this point, we evaluated all the synthesized compounds against a panel of cell lines to identify compounds with activity in tandem with the reported value of the natural product. The results threw up some interesting observations (Table 1). It was observed that tetramer 8 had activity $\left(\mathrm{IC}_{50} 1.5 \mu \mathrm{M}\right)$ comparable to the value reported in the literature for jahanyne 1 ( $\mathrm{IC}_{50} 1.8$ $\mu \mathrm{M})$ against HeLa cells. Both the conjugates 28 and 29 also exhibited the activity in the range of $3.0 \mu \mathrm{M}$ on HeLa cells. ${ }^{3}$ However, 1a was not effective on the same cell lines.

The most active cytotoxic compounds (compounds 8, 28, and 29) were taken toward identifying their mechanistic roles in cell cycle employing DU-145 cancer cell line. ${ }^{28}$ The cell cycle profile depicted compounds (8, 28, and 29) with significant $G_{0} / G_{1}$ arrest at $1 \mu \mathrm{M}$ concentration when compared to vehicle control (Figure 2). An increased percent of late apoptotic cells was observed when treated with these compounds, similar to positive control, doxorubicin (Figure 3A). Elevated expression levels of proapoptotic genes including Bax, Bid, and Caspase-3 were found when treated with cytotoxic compounds $(\mathbf{8}, \mathbf{2 8}$, and 29) for about $24 \mathrm{~h}$ at $1 \mu \mathrm{M}$ concentration as confirmed by the semiquantitative real-time polymerase chain reaction (RTPCR) techniques (Figure 3B). ${ }^{29}$ The immunoblot assay authenticated that BCL-2 antiapoptotic protein was found at lower levels or absent when treated with compounds $\mathbf{8 , 2 8}$, and 29 with concomitant increase in the levels of proapoptotic proteins, BAX and Annexin V (Figure 3C). Thus, the data suggest apoptosis-inducing pathway progresses in these cells by inhibition of BCL-2.

The navitoclax active site of antiapoptotic BCL-2 protein for molecular docking studies was evaluated to understand the basic interactions with the active compounds $(8,28$, and 29$)$ among the series. ${ }^{30,31}$ In the case of compound $\mathbf{2 8}$, the carbonyl group of proline showed hydrogen bond with bridged water 
A

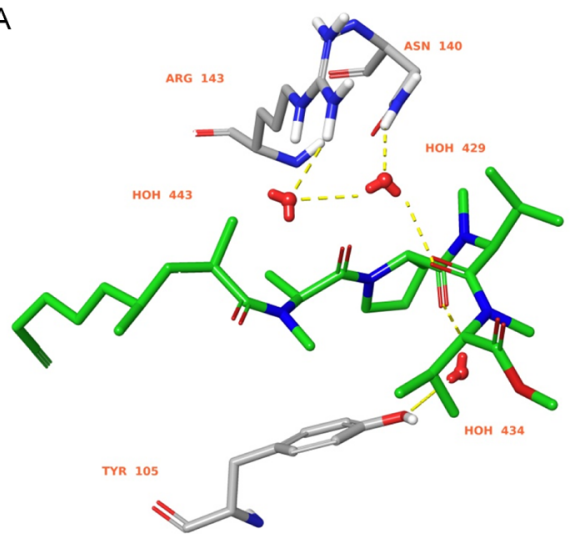

B

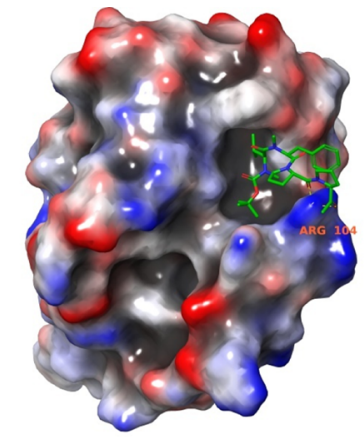

C

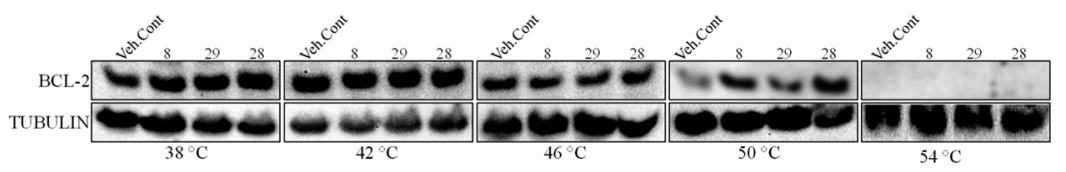

Figure 4. Molecular docking and CETSA of BCL-2 protein with jahanyne congeners (A) interactions of compound 28 with BCL-2 active site, green sticks indicate compound $\mathbf{2 8}$ macromodel sticks point toward amino acids, red color ball and sticks indicate water molecules, and yellow dotted lines indicate hydrogen bonds; (B) surface diagram of compound 8 at P4 binding pocket of BCL-2 active site. (C) CETSA depicting stabilization of BCL2 in the presence of compounds $\mathbf{8}, \mathbf{2 9}$, and 28 at higher temperature $\left(50{ }^{\circ} \mathrm{C}\right)$, indicating binding of these compounds to BCL-2.

molecule between Arg143 and Asn140; the carbonyl group of valine residue depicted a similar kind of $\mathrm{H}$-bond interaction with Trp105 (Figure 4A). Both the Oep and proline carbonyl group of compound $\mathbf{8}$ exhibited two hydrogen bonds (with distances of 1.97 and $2.54 \AA$ ) with side chain of Arg104 at a P4 binding pocket of BCL-2 active site (Figure 4B). Similarly, the terminal carbonyl group of compound 29 had two side-chain hydrogen bonds (with distances of 2.21 and $2.58 \AA$ ) with Arg104, and the another terminal portion was found to be accommodated at P2 domain. The aliphatic chain of both compounds 28 and 29 was found to be occupying the P2 binding groove (Figure S1 see Supporting Information).

To further support the in silico molecular docking of BCL-2, an antiapoptotic protein with compounds 8, 29, and 28 findings, we performed cellular thermal shift assay (CETSA) to elucidate the binding of these compounds to BCL-2 in DU-145 cells. CETSA evaluates the binding of a ligand or a small molecule to its target protein that leads to increased target protein stabilization at differential temperature, as described earlier. $^{32,33}$ Optimum BCL-2 stabilization by compounds 8, 29, and/or 28 binding was observed till $46{ }^{\circ} \mathrm{C}$ (Figure 4C). Cells were treated with 8,29 , and 28 and depicted BCL-2 expression at $50{ }^{\circ} \mathrm{C}$ as compared to unbound protein in vehicle-treated cells. The significant shift in melting temperatures of BCL-2 and its stabilization upon the addition of 8,29 , and 28 indicated that jahanyne congeners may be binding to this antiapoptotic protein (BCL-2).

In summary, we have synthesized pruned congeners of jahanyne using simple and scalable steps. Mechanistic studies indicated that BCL-2 inhibition could be the reason for apoptotic activity of the molecules. The dismal biological activity of desmethyl jahanyne substantiated the observation that N-methylation plays a critical role in the activity of the molecule. Further applications of BCL-2 inhibition in the therapeutic areas of treatment of autoimmune diseases and parasites such as Schistosoma will be explored.

\section{GENERAL INFORMATION}

Unless otherwise noted, all reagents were used as received from commercial suppliers. All nonaqueous reactions were performed under an atmosphere of nitrogen using an oven-dried glassware and a standard syringe in septa techniques. All solvents were dried before use, following the standard procedures. Reactions were monitored using thin-layer chromatography (TLC) $\left(\mathrm{SiO}_{2}\right)$. TLC plates were visualized with UV light $(254 \mathrm{~nm})$, iodine treatment, or using ninhydrin stain. Column chromatography was carried out using silica gel (100-200 mesh) packed in glass columns. NMR spectra were recorded at 300, 400, $500 \mathrm{MHz}(\mathrm{H})$ and at 75, 101, $126 \mathrm{MHz}$ (C). Chemical shifts $(\delta)$ are reported in parts per million, using the residual solvent peak in $\mathrm{CDCl}_{3}(\mathrm{H}: \delta=7.26$ and $\mathrm{C}: \delta=$ $77.16 \mathrm{ppm}$ ) as an internal standard, and coupling constants $(J)$ are given in hertz. High-resolution mass spectrometry (HRMS) was recorded using electrospray ionization (ESI)-Time-offlight techniques. All $\mathrm{N}$-methyl amino acids were prepared according to the procedure described in the literature. ${ }^{34-36}$

\section{BIOLOGICAL DATA}

4.1. Antiproliferative Activity of Compounds. Sulforhodamine $\mathrm{B}$ assay was performed to evaluate the effect of antiproliferative activity of synthesized analogues in various human tissue-specific cancer cell lines breast-MDA-MB-231, prostate-DU-145, lung-A549, cervical-HeLa and control cell line, primary human embryonic kidney cell line-HEK-293. Among these cell lines, DU-145 depicted higher sensitivity toward the synthesized analogues of all the compounds evaluated; compounds $\mathbf{2 8 , 8}$, and 29 were observed to be effective against all the cancer cell types with $\mathrm{IC}_{50}$ values ranging between 0.15 and $3.15 \mu \mathrm{M}$. Doxorubicin, a standard drug, was used as a positive control. These compounds rendered ineffective against HEK-293 ( $\mathrm{IC}_{50} \geq 100 \mu \mathrm{M}$ ), suggesting their nontoxic property against normal cells.

4.2. Effect of Compounds on Cell Cycle Profile. Cell cycle analysis was performed on DU-145 as described in the 
methods using PI staining. The results depicted an increase in the $G_{0} / G_{1}$ arrest in cells treated with compounds 28,8 , and 29 as compared to vehicle control.

4.3. Effect of Compounds on Apoptotic Gene Expression. Gene expression studies were performed with a semiquantitative RT-PCR. Briefly, DU-145 cells were treated with compounds at $1 \mu \mathrm{M}$ concn for $24 \mathrm{~h}$. Proapoptotic genes, Bax and Bid as well as Caspase-3, a programmed cell death marker, were found to be highly expressed in compounds $\mathbf{2 8 , 8}$, and 29 as compared to vehicle control. BCL-2, an antiapoptotic gene expression, was very low to absent in cells treated with compounds 28,8 , and 29 compounds, suggesting a proapoptotic role of these compounds.

4.4. Effect of Compounds on Apoptotic Protein Expression. Antiapoptotic protein marker, BCL-2 expression, was low, whereas proapoptotic marker, BAX and Annexin V, was highly expressed in DU-145 cells treated with compounds 28, 8, and 29 as well as doxorubicin (positive control) when compared with vehicle control. Compound 9 was found to be active against all the cell lines at $1 \mu \mathrm{M}$ concn except for HEK293. These results indicate that Oep moiety is a major contributor to the antiapoptotic activity of compounds synthesized.

\section{EXPERIMENTAL SECTION}

5.1. (S)-6,10-Dimethylundeca-1,9-diene (9). To a stirred solution of $\mathrm{PPh}_{3}(8 \mathrm{~g}, 30.0 \mathrm{mmol})$ and imidazole (4.2 g, 60.0 $\mathrm{mmol})$ in $\mathrm{CH}_{2} \mathrm{Cl}_{2}(20 \mathrm{~mL})$ was added $\mathrm{I}_{2}$ at $0{ }^{\circ} \mathrm{C}$ followed by $R$ (+) citronellol (3.19 g, $20.4 \mathrm{mmol})$ in $\mathrm{CH}_{2} \mathrm{Cl}_{2}(10 \mathrm{~mL})$ and stirred the solution at room temperature $(\mathrm{rt})$ for $1 \mathrm{~h}$. The reaction mixture was quenched with sat. sodium thiosulfate $(20$ $\mathrm{mL})$ and extracted with $\mathrm{CH}_{2} \mathrm{Cl}_{2}(100 \mathrm{~mL})$; the organic layer was washed with brine $(50 \mathrm{~mL})$, then dried over $\mathrm{Na}_{2} \mathrm{SO}_{4}$, and concentrated; and the residue was passed through the celite pad with hexane to afford the iodo compound as a colorless oil (4.9 g). The iodo compound $(4.9 \mathrm{~g}, 18.4 \mathrm{mmol})$ was dissolved in dry THF $(30 \mathrm{~mL})$, and allylmagnesium bromide (1 M, 128 $\mathrm{mL}$ ) was added at $0{ }^{\circ} \mathrm{C}$ and then stirred for $12 \mathrm{~h}$ at rt. Sat. $\mathrm{NH}_{4} \mathrm{Cl}$ was carefully added at $0{ }^{\circ} \mathrm{C}$ and then stirred the reaction mixture for $10 \mathrm{~min}$. The mixture was filtered through the celite pad and extracted with $\mathrm{Et}_{2} \mathrm{O}(3 \times 20 \mathrm{~mL})$. Organic layer was dried over $\mathrm{Na}_{2} \mathrm{SO}_{4}$ and concentrated, and the residue was purified by flash chromatography (hexane) to afford a colorless oil 9 (2.5 g, 70\% in two steps); $[\alpha]_{\mathrm{D}}^{20}-0.68(c=1.0$, $\left.\mathrm{CHCl}_{3}\right) ;{ }^{1} \mathrm{H}$ NMR $\left(500 \mathrm{MHz}, \mathrm{CDCl}_{3}\right): \delta 5.85-5.77(\mathrm{~m}, 1 \mathrm{H})$, 5.13-5.07 (m, 1H), 5.03-4.91 (m, 2H), 2.07-1.89 (m, 4H), $1.68(\mathrm{~s}, 3 \mathrm{H}), 1.60(\mathrm{~s}, 3 \mathrm{H}), 1.46-1.29(\mathrm{~m}, 5 \mathrm{H}), 1.17-1.09(\mathrm{~m}$, $2 \mathrm{H}), 0.87(\mathrm{~d}, J=6.6 \mathrm{~Hz}, 3 \mathrm{H}) ;{ }^{13} \mathrm{C} \mathrm{NMR}\left(101 \mathrm{MHz} \mathrm{CDCl}_{3}\right): \delta$ 139.1, 130.8, 125.0, 114.1, 37.1, 36.5, 34.2, 32.3, 26.4, 25.7, 25.6, 19.6, 17.6; IR (neat): $\nu_{\max } 2970,2839,2173,1606,1511$, 1455, 1378, 1250, 773, $760 \mathrm{~cm}^{-1}$; HRMS (EI-MS) calcd for $\mathrm{C}_{13} \mathrm{H}_{24}[\mathrm{M}]^{+}$: 180.1878 ; found, 180.1872 .

5.2. (S)-6,10-Dimethylundec-9-en-1-ol (10). A flamedried flask was cooled under a stream of nitrogen and charged with diene $9(2.3 \mathrm{~g}, 12.7 \mathrm{mmol})$ and dry THF $(10 \mathrm{~mL})$. A solution of 9-BBN (25 mL, 0.5 M in THF, $12.7 \mathrm{mmol}$ ) was added dropwise, and the resulting mixture was stirred at $\mathrm{rt}$ for $12 \mathrm{~h}$. Then, the reaction was cooled to $\mathrm{rt}$, and an aqueous solution of $\mathrm{NaOH}(3 \mathrm{M}, 10 \mathrm{~mL})$ followed by an aqueous solution of $\mathrm{H}_{2} \mathrm{O}_{2}(30 \%, 10 \mathrm{~mL})$ were added. Stirring was continued at $\mathrm{rt}$ for $6 \mathrm{~h}$. $\mathrm{Et}_{2} \mathrm{O}(50 \mathrm{~mL})$ was added, the layers were separated, and the aqueous layer was extracted with $\mathrm{Et}_{2} \mathrm{O}$ $(3 \times 50 \mathrm{~mL})$. The organic layers were combined, dried over
$\mathrm{Na}_{2} \mathrm{SO}_{4}$, and concentrated under reduced pressure. The crude material was purified by column chromatography (10\% EtOAc/ hexane) to afford colorless oil $10(2.12 \mathrm{~g}, 85 \%) ;[\alpha]_{\mathrm{D}}^{20}-1.05(c$ $\left.=2.1, \mathrm{CHCl}_{3}\right) ;{ }^{1} \mathrm{H} \mathrm{NMR}\left(500 \mathrm{MHz}, \mathrm{CDCl}_{3}\right): \delta 5.10(\mathrm{t}, J=7.1$ $\mathrm{Hz}, 1 \mathrm{H}), 3.63(\mathrm{t}, J=6.7 \mathrm{~Hz}, 2 \mathrm{H}), 2.07-1.89(\mathrm{~m}, 2 \mathrm{H}), 1.68(\mathrm{~s}$ $3 \mathrm{H}), 1.60(\mathrm{~s}, 3 \mathrm{H}), 1.59-1.52(\mathrm{~m}, 2 \mathrm{H}), 1.44-1.24(\mathrm{~m}, 8 \mathrm{H})$, $1.18-1.08(\mathrm{~m}, 2 \mathrm{H}), 0.86(\mathrm{~d}, J=6.6 \mathrm{~Hz}, 3 \mathrm{H}) ;{ }^{13} \mathrm{C}$ NMR $(101$ $\left.\mathrm{MHz}, \mathrm{CDCl}_{3}\right): \delta 131.0,125.0,63.0,37.1,36.9,32.8,32.4,26.8$, 26.1, 25.7, 25.6, 19.6, 17.6; IR (neat): $\nu_{\max } 3471,2957,2934$, 1606, 1456, 1252, 1045, $773 \mathrm{~cm}^{-1}$; HRMS (ESI) calcd for $\mathrm{C}_{13} \mathrm{H}_{27} \mathrm{O}[\mathrm{M}+\mathrm{H}]^{+}$: 199.2056; found, 199.2055.

5.3. (S)-6,10-Dimethylundec-9-enal (11). DMP (6.4 g, $15.1 \mathrm{mmol}$ ) was added at $0{ }^{\circ} \mathrm{C}$ under nitrogen to a solution of alcohol 10 (2.0 g, $10.1 \mathrm{mmol})$ in $\mathrm{CH}_{2} \mathrm{Cl}_{2}(20 \mathrm{~mL})$. The resulting mixture was stirred at $\mathrm{rt}$ for $1 \mathrm{~h}$. A 1:1 saturated $\mathrm{NaHCO}_{3} / \mathrm{Na}_{2} \mathrm{~S}_{2} \mathrm{O}_{3}$ solution $(20 \mathrm{~mL})$ was then added; the aqueous phase was separated and extracted with $\mathrm{CH}_{2} \mathrm{Cl}_{2}(100$ $\mathrm{mL})$. The combined organic extracts were dried $\left(\mathrm{Na}_{2} \mathrm{SO}_{4}\right)$, filtered, and concentrated. Purification of the residue by flash chromatography on silica gel (5\% EtOAc in hexane) gave aldehyde $11(1.7 \mathrm{~g}, 89 \%)$ as a colorless oil; $[\alpha]_{\mathrm{D}}^{20}-0.28(c=$ 3.15, $\mathrm{CHCl}_{3}$ ); ${ }^{1} \mathrm{H}$ NMR (300 MHz, $\left.\mathrm{CDCl}_{3}\right): \delta 9.77(\mathrm{t}, J=1.8$ $\mathrm{Hz}, 1 \mathrm{H}), 5.24-4.93(\mathrm{~m}, 1 \mathrm{H}), 2.44(\mathrm{td}, J=7.3,1.8 \mathrm{~Hz}, 2 \mathrm{H})$, $2.07-1.90(\mathrm{~m}, 2 \mathrm{H}), 1.69(\mathrm{~s}, 3 \mathrm{H}), 1.61(\mathrm{~s}, 4 \mathrm{H}), 1.43-1.27(\mathrm{~m}$, $6 \mathrm{H}), 1.19-1.09(\mathrm{~m}, 2 \mathrm{H}), 0.87(\mathrm{~d}, J=6.4 \mathrm{~Hz}, 3 \mathrm{H}) ;{ }^{13} \mathrm{C} \mathrm{NMR}$ $\left(101 \mathrm{MHz}, \mathrm{CDCl}_{3}\right): \delta 202.4,130.8,124.7,43.7,36.9,36.5$, $32.1,26.4,25.5,25.4,22.2,19.3,17.4 \mathrm{~cm}^{-1}$; HRMS (ESI) calcd for $\mathrm{C}_{13} \mathrm{H}_{25} \mathrm{O}[\mathrm{M}+\mathrm{H}]^{+}$: 197.1900; found, 197.1902.

5.4. (S)-(7,11-Dimethyldodec-10-en-1-yn-1-yl)trimethylsilane (12). $\mathrm{CBr}_{4}(3.31 \mathrm{~g}, 10.2 \mathrm{mmol})$ was added slowly to a solution of $\mathrm{PPh}_{3}(5.24 \mathrm{~g}, 20.4 \mathrm{mmol})$ in $\mathrm{CH}_{2} \mathrm{Cl}_{2}(20$ $\mathrm{mL}$ ) at $0{ }^{\circ} \mathrm{C}$, and stirring was continued for $30 \mathrm{~min}$. A solution of aldehyde $11(1.0 \mathrm{~g}, 5.1 \mathrm{mmol})$ in $\mathrm{CH}_{2} \mathrm{Cl}_{2}(5 \mathrm{~mL})$ was added dropwise at the same temperature, and stirring was continued at $\mathrm{rt}$ for $2 \mathrm{~h}$. The reaction mixture was concentrated and filtered through a celite pad with $\mathrm{Et}_{2} \mathrm{O}$. The solvent was removed in vacuum, and the crude dibromoalkene was dissolved in THF $(20 \mathrm{~mL})$. The solution was cooled to $-78{ }^{\circ} \mathrm{C}$; a solution of $n$ $\operatorname{BuLi}(2.5 \mathrm{M}$ in hexane, $4 \mathrm{~mL}, 10.2 \mathrm{mmol}$ ) was added slowly, and stirring was continued for $1 \mathrm{~h}$. Chlorotrimethylsilane (1.3 $\mathrm{mL}, 10.2 \mathrm{mmol}$ ) was added slowly; the resulting mixture was allowed to warm to $\mathrm{rt}$ and stirred for $12 \mathrm{~h}$. The mixture was poured into saturated aqueous $\mathrm{NH}_{4} \mathrm{Cl}(20 \mathrm{~mL})$. The organic layer was separated, and the aqueous phase was extracted with diethyl ether $(150 \mathrm{~mL})$. The combined organic layers were dried over $\mathrm{Na}_{2} \mathrm{SO}_{4}$ and concentrated in vacuo. Column chromatography on silica gel (hexane) provided the enyne 12 $(0.93 \mathrm{~g}, 72 \%)$ as a colorless oil; $[\alpha]_{\mathrm{D}}^{20}-1.48\left(c=1.0, \mathrm{CHCl}_{3}\right)$; ${ }^{1} \mathrm{H}$ NMR $\left(400 \mathrm{MHz}, \mathrm{CDCl}_{3}\right): \delta 5.09(\mathrm{t}, J=6.7 \mathrm{~Hz}, 1 \mathrm{H}), 2.21$ $(\mathrm{t}, J=7.0 \mathrm{~Hz}, 2 \mathrm{H}), 2.06-1.86(\mathrm{~m}, 2 \mathrm{H}), 1.68(\mathrm{~s}, 3 \mathrm{H}), 1.59(\mathrm{~s}$, $3 \mathrm{H}), 1.54-1.26(\mathrm{~m}, 7 \mathrm{H}), 1.19-1.06(\mathrm{~m}, 2 \mathrm{H}), 0.86(\mathrm{~d}, J=6.5$ $\mathrm{Hz}, 3 \mathrm{H}), 0.14(\mathrm{~s}, 9 \mathrm{H}) ;{ }^{13} \mathrm{C} \mathrm{NMR}\left(101 \mathrm{MHz}, \mathrm{CDCl}_{3}\right): \delta 131.0$, 125.0, 107.7, 84.3, 37.1, 36.3, 32.2, 28.9, 26.1, 25.7, 25.5, 19.8, $19.5,17.6,0.2$; IR (neat): $\nu_{\max } 3312,2954,1721,1606,1315$, 1237, 1156, 1052, 956, $852 \mathrm{~cm}^{-1}$; HRMS (EI-MS) calcd for $\mathrm{C}_{17} \mathrm{H}_{32} \mathrm{Si}[\mathrm{M}]^{+}$: 264.2273; found, 264.2270.

5.5. 4-Methyl-10-(trimethylsilyl)dec-9-ynal (13). Enyne $12(500 \mathrm{mg}, 1.89 \mathrm{mmol})$ and sodium acetate $(162 \mathrm{mg}, 1.98$ $\mathrm{mmol}$ ) were suspended in $\mathrm{CH}_{2} \mathrm{Cl}_{2}(10 \mathrm{~mL})$ and cooled to -20 ${ }^{\circ} \mathrm{C}$. $m$-CPBA $(70 \%, 488 \mathrm{mg}, 1.98 \mathrm{mmol})$ was added in small portions, and stirring was continued for $1.5 \mathrm{~h}$, allowing the suspension to warm to $0{ }^{\circ} \mathrm{C}$. The reaction was quenched by careful addition of saturated aqueous $\mathrm{NaHCO}_{3}(10 \mathrm{~mL})$ and 
extracted with $\mathrm{CH}_{2} \mathrm{Cl}_{2}(3 \times 10 \mathrm{~mL})$. The combined organic fractions were washed with $1 \mathrm{~N} \mathrm{NaOH}(5 \mathrm{~mL})$, dried over $\mathrm{Na}_{2} \mathrm{SO}_{4}$, and concentrated in vacuo. The crude product was dissolved in $\mathrm{Et}_{2} \mathrm{O}(10 \mathrm{~mL})$ and cooled to $0{ }^{\circ} \mathrm{C}$, and $\mathrm{H}_{5} \mathrm{IO}_{6}(647$ $\mathrm{mg}, 2.84 \mathrm{mmol})$ in THF $(15 \mathrm{~mL})$ was added within $45 \mathrm{~min}$. Stirring was continued until TLC analysis showed complete consumption of the starting material. The mixture was diluted with $\mathrm{Et}_{2} \mathrm{O}(30 \mathrm{~mL}) ; \mathrm{H}_{2} \mathrm{O}(10 \mathrm{~mL})$ was added, and the phases were separated. The combined organic layers of residue were washed twice with brine, dried over $\mathrm{Na}_{2} \mathrm{SO}_{4}$, and concentrated in vacuo. Column chromatography on silica gel (5\% EtOAc in hexane) provided the aldehyde $13(372 \mathrm{mg}, 84 \%)$ as a colorless liquid; $[\alpha]_{\mathrm{D}}^{20}-1.07\left(c=1.0, \mathrm{CHCl}_{3}\right) ;{ }^{1} \mathrm{H}$ NMR $(300 \mathrm{MHz}$, $\left.\mathrm{CDCl}_{3}\right): \delta 9.76(\mathrm{t}, J=1.8 \mathrm{~Hz}, 1 \mathrm{H}), 2.53-2.27(\mathrm{~m}, 2 \mathrm{H}), 2.21(\mathrm{t}$, $J=6.9 \mathrm{~Hz}, 2 \mathrm{H}), 1.75-1.58(\mathrm{~m}, 1 \mathrm{H}), 1.55-1.10(\mathrm{~m}, 8 \mathrm{H}), 0.87$ (d, $J=6.2 \mathrm{~Hz}, 3 \mathrm{H}), 0.13(\mathrm{~s}, 9 \mathrm{H}) ;{ }^{13} \mathrm{C}$ NMR $\left(75 \mathrm{MHz}, \mathrm{CDCl}_{3}\right)$ : $\delta$ 202.8, 107.4, 84.4, 41.6, 36.0, 32.2, 28.8, 28.7, 26.0, 19.8, 19.2, 0.1 ; IR (neat): $\nu_{\max } 3315,2942,1716,1605,1532,1239,1156$, 962, $779 \mathrm{~cm}^{-1}$; HRMS (ESI) calcd for $\mathrm{C}_{14} \mathrm{H}_{26} \mathrm{NaOSi}[\mathrm{M}+$ $\mathrm{Na}^{+}$: 261.1645; found, 261.1655.

5.6. (S)-4-Methyl-10-(trimethylsilyl)dec-9-ynoic Acid (14). The aldehyde $13(350 \mathrm{mg}, 1.47 \mathrm{mmol})$ was dissolved in $t$-butanol $(12 \mathrm{~mL})$ and $\mathrm{H}_{2} \mathrm{O}(4 \mathrm{~mL})$. 2-Methyl-2-butene $(1.24 \mathrm{~mL}, 117 \mathrm{mmol})$, sodium dihydrogen phosphate $(710 \mathrm{mg}$, $5.88 \mathrm{mmol})$, and sodium chlorite $(529 \mathrm{mg}, 5.88 \mathrm{mmol})$ were added to the solution, and the mixture was stirred for $1.5 \mathrm{~h}$ at rt. The solvent was removed in vacuo; the residue was dissolved in EtOAc $(200 \mathrm{~mL})$ and washed with brine solution. The aqueous phase was extracted with EtOAc $(3 \times 20 \mathrm{~mL})$; the combined organic layers of residue were washed with brine, dried over $\mathrm{Na}_{2} \mathrm{SO}_{4}$, and concentrated in vacuo. Column chromatography on silica gel (10\% EtOAc in hexane) provided the acid $14(360 \mathrm{mg}, 96 \%)$ as a colorless liquid; $[\alpha]_{\mathrm{D}}^{20}-0.86(c$ $\left.=0.75, \mathrm{CHCl}_{3}\right) ;{ }^{1} \mathrm{H}$ NMR $\left(400 \mathrm{MHz}, \mathrm{CDCl}_{3}\right): \delta 2.42-2.29$ $(\mathrm{m}, 2 \mathrm{H}), 2.21(\mathrm{t}, J=7.0 \mathrm{~Hz}, 2 \mathrm{H}), 1.76-1.60(\mathrm{~m}, 1 \mathrm{H}), 1.56-$ $1.25(\mathrm{~m}, 7 \mathrm{H}), 1.22-1.10(\mathrm{~m}, 1 \mathrm{H}), 0.88(\mathrm{~d}, J=6.3 \mathrm{~Hz}, 3 \mathrm{H})$, $0.13(\mathrm{~s}, 9 \mathrm{H}) ;{ }^{13} \mathrm{C} \mathrm{NMR}\left(101 \mathrm{MHz}, \mathrm{CDCl}_{3}\right): \delta 180.6,107.5$, 84.4, 35.9, 32.2, 31.8, 31.5, 28.7, 25.9, 19.8, 19.1, 0.1; IR (neat): $\nu_{\max } 3321,2954,1758,1726,1521,1043,952,843,768 \mathrm{~cm}^{-1}$; HRMS (ESI) calcd for $\mathrm{C}_{14} \mathrm{H}_{26} \mathrm{NaO}_{2} \mathrm{Si}[\mathrm{M}+\mathrm{Na}]^{+}$: 277.1594; found, 277.1609.

5.7. (R)-4-Benzyl-3-((S)-4-methyl-10-(trimethylsilyl)dec-9-ynoyl)oxazolidin-2-one (15). To a stirred solution of acid 14 (0.36 g, $1.41 \mathrm{mmol})$ and $\mathrm{Et}_{3} \mathrm{~N}(0.5 \mathrm{~mL}, 3.54 \mathrm{mmol})$ in anhydrous THF $(10 \mathrm{~mL})$ at $-20{ }^{\circ} \mathrm{C}$ was added pivaloyl chloride $(0.2 \mathrm{~mL}, 1.55 \mathrm{mmol})$ dropwise, and the mixture was stirred for $1 \mathrm{~h}$ at $-20{ }^{\circ} \mathrm{C}$. Anhydrous $\mathrm{LiCl}(1.01 \mathrm{~g}, 23.93 \mathrm{mmol})$ was then added, and the mixture was stirred for $30 \mathrm{~min}$. To this mixture, a solution of auxiliary $(275 \mathrm{mg}, 1.55 \mathrm{mmol})$ in anhydrous THF was added; the mixture was stirred at $-20{ }^{\circ} \mathrm{C}$ for $1 \mathrm{~h}$ and then allowed to warm to rt. After stirring at ambient temperature for $2 \mathrm{~h}$, the reaction mixture was quenched with sat. $\mathrm{NH}_{4} \mathrm{Cl}$ solution $(15 \mathrm{~mL})$. The organic layer was separated, and the aqueous layer was extracted with EtOAc $(75 \mathrm{~mL})$. The combined organic layers were washed with brine and dried over $\mathrm{Na}_{2} \mathrm{SO}_{4}$ and concentrated in vacuo. Column chromatography on silica gel (10\% EtOAc in hexane) provided imide 15 (0.456 g, 78\%) as a yellow liquid; $[\alpha]_{\mathrm{D}}^{20}-33.38\left(c=2.1, \mathrm{CHCl}_{3}\right) ;{ }^{1} \mathrm{H}$ NMR (400 MHz, $\left.\mathrm{CDCl}_{3}\right): \delta 7.38-7.16(\mathrm{~m}, 5 \mathrm{H}), 4.69-4.62$ (m, $1 \mathrm{H}), 4.24-4.09(\mathrm{~m}, 2 \mathrm{H}), 3.27(\mathrm{dd}, J=13.4,3.2 \mathrm{~Hz}, 1 \mathrm{H})$, 2.99-2.88 (m, 2H), $2.75(\mathrm{dd}, J=13.3,9.6 \mathrm{~Hz}, 1 \mathrm{H}), 2.21(\mathrm{t}, J=$ $7.0 \mathrm{~Hz}, 2 \mathrm{H}), 1.82-1.63(\mathrm{~m}, 1 \mathrm{H}), 1.59-1.13(\mathrm{~m}, 8 \mathrm{H}), 0.91(\mathrm{~d}, J$ $=6.3 \mathrm{~Hz}, 3 \mathrm{H}), 0.13(\mathrm{~s}, 9 \mathrm{H}) ;{ }^{13} \mathrm{C} \mathrm{NMR}\left(75 \mathrm{MHz}, \mathrm{CDCl}_{3}\right): \delta$
173.6, 153.4, 135.3, 129.4, 128.9, 127.3, 107.5, 84.3, 66.1, 55.1, $37.9,36.1,33.3,32.3,31.2,28.8,26.0,19.8,19.3,0.1$; IR (neat): $\nu_{\max } 3328,1788,1717,1521,1142,1052,992,773 \mathrm{~cm}^{-1}$; HRMS (ESI) calcd for $\mathrm{C}_{24} \mathrm{H}_{35} \mathrm{NNaO}_{3} \mathrm{Si}[\mathrm{M}+\mathrm{Na}]^{+}$: 436.2278; found, 436.2297.

5.8. (R)-4-Benzyl-3-((2R,4S)-2,4-dimethyl-10(trimethylsilyl)dec-9-ynoyl)oxazolidin-2-one (16). To a stirred solution of 15 (350 $\mathrm{mg}, 0.847 \mathrm{mmol})$ in anhydrous THF $(8 \mathrm{~mL})$ under nitrogen was added NaHMDS ( $1 \mathrm{M}$ in THF, 1.0 $\mathrm{mL}, 1.01 \mathrm{mmol})$ at $-78{ }^{\circ} \mathrm{C}$. After stirring for $30 \mathrm{~min}$, methyl iodide $(0.53 \mathrm{~mL}, 8.47 \mathrm{mmol})$ was added and the mixture was stirred at $-78{ }^{\circ} \mathrm{C}$ for another $1 \mathrm{~h}$. The reaction mixture was quenched with saturated aqueous $\mathrm{NH}_{4} \mathrm{Cl}$ solution $(10 \mathrm{~mL})$. The combined organic layers were washed with brine, dried over $\mathrm{Na}_{2} \mathrm{SO}_{4}$, and concentrated in vacuo. Column chromatography on silica gel (10\% EtOAc in hexane) provided 16 (275 $\mathrm{mg}, 76 \%)$ as a yellow liquid; $[\alpha]_{\mathrm{D}}^{20}-50.43\left(c=1.75, \mathrm{CHCl}_{3}\right)$; ${ }^{1} \mathrm{H}$ NMR $\left(500 \mathrm{MHz}, \mathrm{CDCl}_{3}\right): \delta 7.33(\mathrm{dd}, J=10.0,4.5 \mathrm{~Hz}$, $2 \mathrm{H}$ ), 7.30-7.25 (m, 1H), 7.24-7.19 (m, 2H), 4.71-4.59 (m, $1 \mathrm{H}), 4.27-4.10(\mathrm{~m}, 2 \mathrm{H}), 3.91-3.75(\mathrm{~m}, 1 \mathrm{H}), 3.27(\mathrm{dd}, J=$ 13.3, $3.2 \mathrm{~Hz}, 1 \mathrm{H}), 2.76(\mathrm{dd}, J=13.3,9.6 \mathrm{~Hz}, 1 \mathrm{H}), 2.20(\mathrm{t}, J=$ $7.1 \mathrm{~Hz}, 2 \mathrm{H}), 1.57-1.38(\mathrm{~m}, 6 \mathrm{H}), 1.37-1.25(\mathrm{~m}, 2 \mathrm{H}), 1.20(\mathrm{~d}, J$ $=6.8 \mathrm{~Hz}, 3 \mathrm{H}), 1.17-1.10(\mathrm{~m}, 1 \mathrm{H}), 0.88(\mathrm{~d}, J=6.4 \mathrm{~Hz}, 3 \mathrm{H})$, $0.14(\mathrm{~s}, 9 \mathrm{H}) ;{ }^{13} \mathrm{C}$ NMR $\left(101 \mathrm{MHz}, \mathrm{CDCl}_{3}\right): \delta 177.7,153.0$, 135.3, 129.4, 128.9, 127.3, 107.5, 84.4, 66.0, 55.4, 40.4, 37.9, $36.6,35.4,30.3,28.7,26.0,19.8,19.2,17.2,0.2$; IR (neat): $\nu_{\max }$ 3328, 1768, 1737, 1551, 1198, 1074, 984, $763 \mathrm{~cm}^{-1}$; HRMS (ESI) calcd for $\mathrm{C}_{25} \mathrm{H}_{37} \mathrm{NNaO}_{3} \mathrm{Si}[\mathrm{M}+\mathrm{Na}]^{+}$: 450.2435; found, 450.2456.

5.9. (R)-4-Benzyl-3-((2R,4S)-2,4-dimethyldec-9-ynoyl)oxazolidin-2-one (17). To a solution of 16 (0.25 g, 0.58 $\mathrm{mmol})$ in THF $(10 \mathrm{~mL})$ at $-10{ }^{\circ} \mathrm{C}$ was added TBAF $(1.0 \mathrm{M} /$ THF, $1.46 \mathrm{~mL}, 1.46 \mathrm{mmol}$ ) over $15 \mathrm{~min}$. The resulting orange solution was stirred for $1 \mathrm{~h}$ at this temperature then diluted with EtOAc $(50 \mathrm{~mL})$. The residue was washed with sat. $\mathrm{NH}_{4} \mathrm{Cl}$ and brine and dried over $\mathrm{Na}_{2} \mathrm{SO}_{4}$ and concentrated in vacuo. The crude was purified by flash chromatography (10\% EtOAc/ hexane) to afford $17(0.193 \mathrm{~g}, 93 \%)$ as a colorless liquid; $[\alpha]_{\mathrm{D}}^{20}$ $-49.40\left(c=0.6, \mathrm{CHCl}_{3}\right) ;{ }^{1} \mathrm{H}$ NMR (500 MHz, $\left.\mathrm{CDCl}_{3}\right): \delta 7.33$ (dd, $J=10.0,4.5 \mathrm{~Hz}, 2 \mathrm{H}), 7.29-7.26(\mathrm{~m}, 1 \mathrm{H}), 7.24-7.19(\mathrm{~m}$, $2 \mathrm{H}), 4.74-4.58(\mathrm{~m}, 1 \mathrm{H}), 4.28-4.10(\mathrm{~m}, 2 \mathrm{H}), 3.89-3.78(\mathrm{~m}$, $1 \mathrm{H}), 3.27(\mathrm{dd}, J=13.4,3.3 \mathrm{~Hz}, 1 \mathrm{H}), 2.76(\mathrm{dd}, J=13.4,9.6 \mathrm{~Hz}$, $1 \mathrm{H}), 2.20-2.16(\mathrm{~m}, 2 \mathrm{H}), 1.93(\mathrm{t}, J=2.6 \mathrm{~Hz}, 1 \mathrm{H}), 1.59-1.23$ $(\mathrm{m}, 9 \mathrm{H}), 1.20(\mathrm{~d}, J=6.8 \mathrm{~Hz}, 3 \mathrm{H}), 0.89(\mathrm{~d}, J=6.4 \mathrm{~Hz}, 3 \mathrm{H}) ;{ }^{13} \mathrm{C}$ NMR $\left(75 \mathrm{MHz}, \mathrm{CDCl}_{3}\right): \delta 177.6,153.0,135.3,129.4,128.9$, 127.3, 84.6, 68.1, 66.0, 55.4, 40.4, 37.9, 36.7, 35.4, 30.3, 28.6, 26.0, 19.2, 18.3, 17.1; IR (neat): $\nu_{\max } 3016,1768,1732,1511$, 1162, 1095, 992, 762, cm ${ }^{-1}$; HRMS (ESI) calcd for $\mathrm{C}_{22} \mathrm{H}_{29} \mathrm{NNaO}_{3}[\mathrm{M}+\mathrm{Na}]^{+}$: 378.2040; found, 378.2063.

5.10. (2R,4S)-2,4-Dimethyldec-9-ynoic Acid (2). To a solution of $17(180 \mathrm{mg}, 0.5 \mathrm{mmol})$ in THF $(10 \mathrm{~mL})$ were added hydrogen peroxide ( $245 \mathrm{mg}, 2.5 \mathrm{mmol}, 35 \%)$ and $\mathrm{LiOH}$. $\mathrm{H}_{2} \mathrm{O}(42 \mathrm{mg}, 1.0 \mathrm{mmol})$ at $0{ }^{\circ} \mathrm{C}$. After $5 \mathrm{~min}$ at $0{ }^{\circ} \mathrm{C}$, the reaction mixture was allowed to $\mathrm{rt}$ and stirred for $2 \mathrm{~h}$. The reaction mixture was cooled to $0{ }^{\circ} \mathrm{C}$ and quenched with sat. $\mathrm{Na}_{2} \mathrm{SO}_{3}$ at $0{ }^{\circ} \mathrm{C}$. The residue was diluted with $\mathrm{H}_{2} \mathrm{O}$, acidified with $9 \mathrm{M} \mathrm{HCl}$ until $\mathrm{pH}$ reached to 2.0 , and extracted with EtOAc $(3 \times 10 \mathrm{~mL})$. The combined organic layers were washed with brine, dried over $\mathrm{Na}_{2} \mathrm{SO}_{4}$, and concentrated in vacuo. Column chromatography on silica gel (10\% EtOAc in hexane) provided $2(90 \mathrm{mg}, 90 \%)$ as a colorless liquid; $[\alpha]_{\mathrm{D}}^{20}$ $-3.61\left(c=1.5, \mathrm{CHCl}_{3}\right) ;{ }^{1} \mathrm{H} \mathrm{NMR}\left(400 \mathrm{MHz}, \mathrm{CDCl}_{3}\right): \delta 2.59-$ $2.47(\mathrm{~m}, 1 \mathrm{H}), 2.18(\mathrm{td}, J=6.9,2.5 \mathrm{~Hz}, 2 \mathrm{H}), 1.94(\mathrm{t}, J=2.6 \mathrm{~Hz}$, 
$1 \mathrm{H}), 1.62-1.44(\mathrm{~m}, 4 \mathrm{H}), 1.43-1.30(\mathrm{~m}, 5 \mathrm{H}), 1.15(\mathrm{~d}, J=6.9$ $\mathrm{Hz}, 3 \mathrm{H}), 0.87(\mathrm{~d}, J=6.3 \mathrm{~Hz}, 3 \mathrm{H}) ;{ }^{13} \mathrm{C}$ NMR $(101 \mathrm{MHz}$, $\left.\mathrm{CDCl}_{3}\right): \delta$ 183.6, 84.6, 68.2, 40.7, 37.1, 36.4, 30.4, 28.9, 26.0, 19.3, 18.4, 16.8; IR (neat): $\nu_{\max } 3315,1757,1561,1102,1085$, 962, $753 \mathrm{~cm}^{-1}$; HRMS (ESI) calcd for $\mathrm{C}_{12} \mathrm{H}_{19} \mathrm{O}_{2}[\mathrm{M}-\mathrm{H}]^{-}$: 195.1380; found, 195.1391.

5.11. N-Me-N-Boc-L-Ala-L-Pro-N-Me-L-Val-OMe (19). To a stirred solution of dimer $18(1 \mathrm{~g}, 3.18 \mathrm{mmol})$ in $\mathrm{MeOH} / \mathrm{H}_{2} \mathrm{O}$ $(7: 3,10 \mathrm{~mL})$ was added $\mathrm{LiOH} \cdot \mathrm{H}_{2} \mathrm{O}(400 \mathrm{mg}, 9.5 \mathrm{mmol})$, and the reaction mixture was stirred at $\mathrm{rt}$ for $3 \mathrm{~h}$. After that, the solvent $(\mathrm{MeOH})$ was removed in vacuo and the resulting mixture was acidified with $1 \mathrm{M} \mathrm{HCl}(0.3 \mathrm{~mL})$ to $\mathrm{pH} 4$ and extracted with EtOAc $(3 \times 10 \mathrm{~mL})$. The combined organic layer was washed with brine, dried over $\mathrm{Na}_{2} \mathrm{SO}_{4}$, and concentrated. The crude material was dissolved in dry dimethylformamide (DMF) $(5 \mathrm{~mL})$. To this, the trifluoroacetate salt of $N$-methyl valine ester $(0.62 \mathrm{~g}, 2.51 \mathrm{mmol})$, dry DMF $(3 \mathrm{~mL})$ and DIPEA $(1.8 \mathrm{~mL}, 10.04 \mathrm{mmol})$ were added at rt. The suspension was stirred for $10 \mathrm{~min}$, and HATU (1.43 g, $3.76 \mathrm{mmol}$ ) was added under $\mathrm{N}_{2}$ atmosphere. After stirring for $12 \mathrm{~h}$, the reaction mixture was diluted with EtOAc and washed with $10 \%$ aq citric acid $(20 \mathrm{~mL})$ and sat. $\mathrm{NaHCO}_{3}(20 \mathrm{~mL})$. The organic layer was washed with brine, dried over $\mathrm{Na}_{2} \mathrm{SO}_{4}$, and concentrated. The residue was purified by column chromatography on silica gel (50\% EtOAc in hexane) to give the trimer $19(1.08 \mathrm{~g}, 80 \%)$ as a colorless liquid; $[\alpha]_{\mathrm{D}}^{20}-174.82$ $\left(c=2.0, \mathrm{CHCl}_{3}\right)$; mixture of rotamers $(9: 1),{ }^{1} \mathrm{H}$ NMR (400 $\left.\mathrm{MHz} \mathrm{CDCl}_{3}\right): \delta 4.99-4.92(\mathrm{~m}, 0.5 \mathrm{H}), 4.84-4.64(\mathrm{~m}, 2.5 \mathrm{H})$, $3.73-3.67(\mathrm{~m}, 0.5 \mathrm{H}), 3.63(\mathrm{~s}, 3 \mathrm{H}), 3.56-3.33(\mathrm{~m}, 1.5 \mathrm{H}), 3.05$ (s, $2.7 \mathrm{H}), 2.89(\mathrm{~s}, 0.3 \mathrm{H}), 2.81(\mathrm{~s}, 0.4 \mathrm{H}), 2.76-2.70(\mathrm{~m}, 2.6 \mathrm{H})$, $2.31-2.03(\mathrm{~m}, 3 \mathrm{H}), 1.93-1.78(\mathrm{~m}, 2 \mathrm{H}), 1.39(\mathrm{~s}, 9 \mathrm{H}), 1.24-$ $1.15(\mathrm{~m}, 3 \mathrm{H}), 0.94-0.91(\mathrm{~m}, 3 \mathrm{H}), 0.88-0.85(\mathrm{~m}, 3 \mathrm{H}) ;{ }^{13} \mathrm{C}$ NMR $\left(126 \mathrm{MHz}, \mathrm{CDCl}_{3}\right): \delta 172.8,171.7,170.0,169.2,155.4$, $154.8,80.0,79.6,65.3,61.5,61.4,56.7,56.5,53.5,51.5,51.5$, $46.7,46.4,38.4,31.1,29.4,29.0,28.2,27.4,25.6,24.6,19.5$, $18.9,18.5,14.0,13.6$; IR (neat): $\nu_{\max } 2932,2864,1751,1684$, 1617, 1481, 1266, 1059, 972, $840 \mathrm{~cm}^{-1}$; HRMS (ESI) calcd for $\mathrm{C}_{21} \mathrm{H}_{37} \mathrm{~N}_{3} \mathrm{NaO}_{6}[\mathrm{M}+\mathrm{Na}]^{+}:$450.2575; found, 450.2583 .

5.12. Tetramer 7. To a stirring solution of trimer $19(0.5 \mathrm{~g}$, $1.17 \mathrm{mmol})$ in $\mathrm{MeOH} / \mathrm{H}_{2} \mathrm{O}(7: 3,10 \mathrm{~mL})$ was added $\mathrm{LiOH}$. $\mathrm{H}_{2} \mathrm{O}$ (147 mg, $3.5 \mathrm{mmol}$ ), and the reaction mixture was stirred at $\mathrm{rt}$ for $3 \mathrm{~h}$. After that, the solvent $(\mathrm{MeOH})$ was removed in vacuo and the resulting mixture was acidified with $1 \mathrm{M} \mathrm{HCl}$ $(0.3 \mathrm{~mL})$ to $\mathrm{pH} 4$ and extracted with EtOAc $(3 \times 10 \mathrm{~mL})$. The combined organic layer was washed with brine, dried over $\mathrm{Na}_{2} \mathrm{SO}_{4}$, and concentrated. The crude was dissolved in dry DMF ( $3 \mathrm{~mL})$; to this, the trifluoroacetate salt of $N$-methyl valine ester $(0.219 \mathrm{~g}, 0.895 \mathrm{mmol})$, dry DMF $(2 \mathrm{~mL})$ and DIPEA $(0.62 \mathrm{~mL}, 3.58 \mathrm{mmol})$ were added at rt. The suspension was stirred for $10 \mathrm{~min}$, and HATU (0.51 g, 1.34 mmol) was added under $\mathrm{N}_{2}$ atmosphere. After stirring for $12 \mathrm{~h}$, the reaction mixture was diluted with EtOAc and washed with $10 \%$ aq citric acid $(20 \mathrm{~mL})$ and sat. $\mathrm{NaHCO}_{3}(20 \mathrm{~mL})$. The organic layer was washed with brine, dried over $\mathrm{Na}_{2} \mathrm{SO}_{4}$, and concentrated. The residue was purified by column chromatography on silica gel (50\% EtOAc in hexane) to give tetramer 7 (440 mg, 70\%) as a colorless liquid; $[\alpha]_{\mathrm{D}}^{20}-125.97(c=1.3$, $\mathrm{CHCl}_{3}$ ); mixture of rotamers (7:2), ${ }^{1} \mathrm{H}$ NMR (500 MHz, $\left.\mathrm{CDCl}_{3}\right): \delta 5.11(\mathrm{~d}, J=10.7 \mathrm{~Hz}, 0.8 \mathrm{H}), 5.06-4.99(\mathrm{~m}, 0.9 \mathrm{H})$, $4.84(\mathrm{~d}, J=11.1 \mathrm{~Hz}, 1 \mathrm{H}), 4.79(\mathrm{~d}, J=13.1 \mathrm{~Hz}, 1.1 \mathrm{H}), 4.40(\mathrm{~d}, J$ $=8.9 \mathrm{~Hz}, 0.2 \mathrm{H}), 3.84(\mathrm{dd}, J=7.3,4.6 \mathrm{~Hz}, 0.2 \mathrm{H}), 3.67(\mathrm{~s}, 3 \mathrm{H})$, $3.61-3.43(\mathrm{~m}, 1.8 \mathrm{H}), 3.08(\mathrm{~s}, 2.5 \mathrm{H}), 3.02(\mathrm{~s}, 2.7 \mathrm{H}), 2.97(\mathrm{~s}$, $0.3 \mathrm{H}), 2.86(\mathrm{~s}, 0.5 \mathrm{H}), 2.76(\mathrm{~s}, 2.4 \mathrm{H}), 2.71(\mathrm{~s}, 0.6 \mathrm{H}), 2.41-2.28$ $(\mathrm{m}, 1.5 \mathrm{H}), 2.21-2.08(\mathrm{~m}, 2.3 \mathrm{H}), 2.03-1.82(\mathrm{~m}, 1.4 \mathrm{H}), 1.91(\mathrm{~s}$, $0.8 \mathrm{H}), 1.43(\mathrm{~s}, 7 \mathrm{H}), 1.39(\mathrm{~s}, 2 \mathrm{H}), 1.24(\mathrm{~d}, J=9.6 \mathrm{~Hz}, 3 \mathrm{H})$, 1.04-1.01 (m, 1H), 1.00-0.97 (m, 2H), 0.93-0.90 (m, 3H), $0.90-0.87(\mathrm{~m}, 3 \mathrm{H}), 0.87-0.85(\mathrm{~m}, 1 \mathrm{H}), 0.75-0.73(\mathrm{~m}, 2 \mathrm{H})$; ${ }^{13} \mathrm{C}$ NMR $\left(75 \mathrm{MHz}, \mathrm{CDCl}_{3}\right): \delta 172.6,171.6,171.2,170.7$, $155.5,154.9,80.2,79.8,64.3,61.3,58.4,57.9,57.2,56.9,53.7$, $51.8,51.6,46.8,46.5,31.5,30.2,30.1,29.8,29.5,29.1,28.4$, 27.6, 27.4, 27.0, 24.7, 20.0, 19.9, 19.1, 18.9, 18.6, 18.3, 14.1; IR (neat): $\nu_{\max } 2973,2876,2839,1740,1676,1651,1535,1442$, 1390, 1150, 1081, 868, $771 \mathrm{~cm}^{-1}$; HRMS (ESI) calcd for $\mathrm{C}_{27} \mathrm{H}_{48} \mathrm{~N}_{4} \mathrm{NaO}_{7}[\mathrm{M}+\mathrm{Na}]^{+}$: 563.3415; found, 563.3443.

5.13. tert-Butyl(S)-2-((S)-2-acetylpyrrolidine-1carbonyl)pyrrolidine-1-carboxylate (21). To a stirred solution of Oep $20(1.0 \mathrm{~g}, 4.69 \mathrm{mmol})$ in $\mathrm{CH}_{2} \mathrm{Cl}_{2}(10 \mathrm{~mL})$ was added TFA $(0.68 \mathrm{~mL}, 13.1 \mathrm{mmol})$, and the reaction mixture was stirred at $0{ }^{\circ} \mathrm{C}$ for $1 \mathrm{~h}$ and at rt for $1 \mathrm{~h}$. After completion of the reaction, benzene $(5 \mathrm{~mL})$ was added to the reaction mixture and concentrated. After repetition of this operation five times, the trifluoroacetate salt of deprotected $\mathbf{2 0}$ was afforded and used in the next reaction without purification. To a $50 \mathrm{~mL}$ RB flask, trifluoroacetate salt of deprotected $\mathbf{2 0}$, dry DMF and dry DIPEA $(3.3 \mathrm{~mL}, 18.7 \mathrm{mmol})$ were added at rt; to this, acid $N$-Boc-L-proline $(1.21 \mathrm{~g}, 5.6 \mathrm{mmol})$ in dry DMF $(3 \mathrm{~mL})$ was added. The suspension was stirred for $10 \mathrm{~min}$, and HATU (2.67 g, $7.0 \mathrm{mmol}$ ) was added under $\mathrm{N}_{2}$ atmosphere. After stirring for $6 \mathrm{~h}$, the reaction mixture was diluted with EtOAc and washed with $10 \%$ aq citric acid $(20 \mathrm{~mL})$ and sat. $\mathrm{NaHCO}_{3}(20 \mathrm{~mL})$. The organic layer was washed with brine, dried over $\mathrm{Na}_{2} \mathrm{SO}_{4}$, and concentrated. The residue was purified by column chromatography on silica gel (50\% EtOAc in hexane) to give the $21(1.16 \mathrm{~g}, 80 \%)$ as a colorless liquid; $[\alpha]_{\mathrm{D}}^{20}$ $-84.57\left(c=2.55, \mathrm{CHCl}_{3}\right)$; mixture of rotamers $(2: 1),{ }^{1} \mathrm{H}$ NMR $\left(500 \mathrm{MHz}, \mathrm{CDCl}_{3}\right): \delta 4.61(\mathrm{dd}, J=8.8,4.7 \mathrm{~Hz}, 0.6 \mathrm{H}), 4.57$ (dd, $J=8.5,4.5 \mathrm{~Hz}, 0.4 \mathrm{H}), 4.43$ (dd, $J=8.5,3.0 \mathrm{~Hz}, 0.6 \mathrm{H}$ ), $4.32(\mathrm{dd}, J=8.4,4.0 \mathrm{~Hz}, 0.4 \mathrm{H}), 3.75-3.68(\mathrm{~m}, 0.6 \mathrm{H}), 3.62-$ $3.56(\mathrm{~m}, 0.4 \mathrm{H}), 3.55-3.45(\mathrm{~m}, 2 \mathrm{H}), 3.42-3.36(\mathrm{~m}, 0.4 \mathrm{H})$, 3.34-3.29 (m, 0.6H), $2.14(\mathrm{~s}, 1 \mathrm{H}), 2.13(\mathrm{~s}, 2 \mathrm{H}), 2.09-1.91(\mathrm{~m}$, $5 \mathrm{H}), 1.83-1.70(\mathrm{~m}, 3 \mathrm{H}), 1.38(\mathrm{~s}, 6 \mathrm{H}), 1.33(\mathrm{~s}, 3 \mathrm{H}) ;{ }^{13} \mathrm{C} \mathrm{NMR}$ $\left(126 \mathrm{MHz}, \mathrm{CDCl}_{3}\right): \delta 206.9,206.5,171.6,171.1,154.6,79.5$, 64.8, 57.6, 46.9, 46.8, 30.2, 29.2, 28.5, 28.4, 27.6, 27.5, 27.5, 27.3, 25.0, 25.0, 24.1, 23.6; IR (neat): $\nu_{\max } 2955,2924,1853$, 1691, 1655, 1414, 1163, 1088, 848, $673 \mathrm{~cm}^{-1}$; HRMS (ESI) calcd for $\mathrm{C}_{16} \mathrm{H}_{26} \mathrm{~N}_{2} \mathrm{NaO}_{4}[\mathrm{M}+\mathrm{Na}]^{+}$: 333.1785; found, 333.1803.

5.14. (2S)-tert-Butyl 2-((2S)-2-(1-Hydroxyethyl)pyrrolidine-1-carbonyl)pyrrolidine-1-carboxylate (22). To a stirred solution of compound $21(500 \mathrm{mg}, 1.61 \mathrm{mmol})$ in dry $\mathrm{MeOH}(5 \mathrm{~mL})$ was added $\mathrm{NaBH}_{4}(121 \mathrm{mg}, 3.2 \mathrm{mmol})$ under a $\mathrm{N}_{2}$ atmosphere, and the reaction solution was stirred at $0{ }^{\circ} \mathrm{C}$ for $1 \mathrm{~h}$ and at $\mathrm{rt}$ for $1 \mathrm{~h}$. After completion of the reaction, sat. $\mathrm{NH}_{4} \mathrm{Cl}(10 \mathrm{~mL})$ was added to the reaction mixture and extracted with EtOAc $(3 \times 10 \mathrm{~mL})$. The combined organic layer was washed with brine $(10 \mathrm{~mL})$, dried over anhydrous $\mathrm{Na}_{2} \mathrm{SO}_{4}$, and concentrated. The residue was purified by column chromatography on silica gel (70\% EtOAc in hexane) to afford alcohol 22 (425 mg, 85\%) as a colorless oil. This was an inseparable mixture of epimers $(2: 1),[\alpha]_{\mathrm{D}}^{20}-39.57(c=1.45$, $\left.\mathrm{CHCl}_{3}\right) ;{ }^{1} \mathrm{H}$ NMR $\left(400 \mathrm{MHz}, \mathrm{CDCl}_{3}\right): \delta$ 4.61-4.38 (m, $0.8 \mathrm{H}), 4.34-3.94(\mathrm{~m}, 1.2 \mathrm{H}), 3.94-3.82(\mathrm{~m}, 0.7 \mathrm{H}), 3.81-3.53$ $(\mathrm{m}, 2.3 \mathrm{H}), 3.52-3.35(\mathrm{~m}, 2 \mathrm{H}), 2.30-2.15(\mathrm{~m}, 1 \mathrm{H}), 2.15-2.02$ $(\mathrm{m}, 2 \mathrm{H}), 2.02-1.80(\mathrm{~m}, 4 \mathrm{H}), 1.76-1.60(\mathrm{~m}, 1 \mathrm{H}), 1.46(\mathrm{~s}$, $4.5 \mathrm{H}), 1.43(\mathrm{~s}, 1.5 \mathrm{H}), 1.40(\mathrm{~s}, 3 \mathrm{H}), 1.23-1.14(\mathrm{~m}, 1.5 \mathrm{H}), 1.03$ $(\mathrm{d}, J=6.3 \mathrm{~Hz}, 1.5 \mathrm{H}) ;{ }^{13} \mathrm{C} \mathrm{NMR}\left(101 \mathrm{MHz}, \mathrm{CDCl}_{3}\right): \delta 175.1$, 
$174.9,173.9,173.2,172.2,154.5,153.6,79.7,79.5,72.0,71.7$, $69.9,69.3,64.9,64.7,64.6,64.5,58.5,58.1,57.9,57.7,48.2$, 47.2 , 46.8, 46.7, 46.5, 45.4, 30.7, 29.7, 28.4, 28.3, 28.0, 27.7, 27.7, 27.2, 24.7, 24.6, 24.5, 24.1, 23.5, 21.3, 21.2, 19.5, 17.4; IR (neat): $\nu_{\max } 2963,2920,2851,1743,1698,1654,1463,1400$, 1365, 1164, $753 \mathrm{~cm}^{-1}$; HRMS (ESI) calcd for $\mathrm{C}_{16} \mathrm{H}_{28} \mathrm{~N}_{2} \mathrm{NaO}_{4}$ $[\mathrm{M}+\mathrm{Na}]^{+}:$335.1941; found, 335.1948.

5.15. Trimer 23. To a stirred solution of alcohol 22 (400 $\mathrm{mg}, 1.28 \mathrm{mmol})$ in $\mathrm{CH}_{2} \mathrm{Cl}_{2}(10 \mathrm{~mL})$ was added TFA $(0.27 \mathrm{~mL}$, $3.5 \mathrm{mmol}$ ), and the reaction mixture was stirred at $0{ }^{\circ} \mathrm{C}$ for $1 \mathrm{~h}$ and at $\mathrm{rt}$ for $1 \mathrm{~h}$. After completion of the reaction, benzene ( 5 $\mathrm{mL}$ ) was added to the reaction mixture and concentrated. After repetition of this operation five times, the trifluoroacetate salt of deprotected 22 was afforded and used in the next reaction without purification. To a $50 \mathrm{~mL}$ RB flask, triflouroacetate salt of deprotected 22, dry DMF and dry DIPEA (0.9 mL, 5.12 $\mathrm{mmol})$ were added at $\mathrm{rt}$; to this, acid N-Boc-L-Phe $(429 \mathrm{mg}$, $1.53 \mathrm{mmol}$ ) in dry DMF (3 mL) was added. The suspension was stirred for $10 \mathrm{~min}$ and HATU $(730 \mathrm{mg}, 1.92 \mathrm{mmol}$ ) was added under $\mathrm{N}_{2}$ atmosphere. After stirring for $12 \mathrm{~h}$, the reaction mixture was diluted with EtOAc and washed with $10 \%$ aq citric acid $(20 \mathrm{~mL})$ and sat. $\mathrm{NaHCO}_{3}(20 \mathrm{~mL})$. The organic layer was washed with brine, dried over $\mathrm{Na}_{2} \mathrm{SO}_{4}$, and concentrated to afford crude-modified dipeptide alcohol $(436 \mathrm{mg})$. To a stirred solution of modified dipeptide alcohol $(436 \mathrm{mg})$ in $\mathrm{CH}_{2} \mathrm{Cl}_{2}(10$ $\mathrm{mL}$ ) was added DMP (586 $\mathrm{mg}, 1.38 \mathrm{mmol})$, and the reaction solution was stirred at $0{ }^{\circ} \mathrm{C}$ for $3 \mathrm{~h}$. After completion of the reaction, the reaction mixture was diluted with saturated aqueous $\mathrm{Na}_{2} \mathrm{~S}_{2} \mathrm{O}_{3}(10 \mathrm{~mL})$ and extracted with EtOAc $(3 \times 10$ $\mathrm{mL})$. The combined organic layer was washed with saturated aqueous $\mathrm{NaHCO}_{3}(10 \mathrm{~mL})$ and brine $(10 \mathrm{~mL})$, dried over anhydrous $\mathrm{Na}_{2} \mathrm{SO}_{4}$, and concentrated. The residue was purified by column chromatography on silica gel ( $80 \%$ EtOAc in hexane) to give $23(368 \mathrm{mg}, 61 \%)$ as a colorless liquid; $[\alpha]_{\mathrm{D}}^{20}$ $-111.96\left(c=0.65, \mathrm{CHCl}_{3}\right)$; mixture of rotamers, $(2: 1),\left({ }^{1} \mathrm{H}\right.$ $\left.\mathrm{NMR}, 400 \mathrm{MHz}, \mathrm{CDCl}_{3}\right): \delta 7.25-7.07(\mathrm{~m}, 5 \mathrm{H}), 5.28-5.22$ $(\mathrm{m}, 0.4 \mathrm{H}), 4.93(\mathrm{dd}, J=10.3,4.6 \mathrm{~Hz}, 0.6 \mathrm{H}), 4.7-4.4(\mathrm{~m}, 2 \mathrm{H})$, $3.88-3.78(\mathrm{~m}, 1 \mathrm{H}), 3.73-3.61(\mathrm{~m}, 1 \mathrm{H}), 3.61-3.50(\mathrm{~m}, 1.4 \mathrm{H})$, $3.37-3.28(\mathrm{~m}, 0.6 \mathrm{H}), 3.11-3.01(\mathrm{~m}, 0.5 \mathrm{H}), 3.01-2.90(\mathrm{~m}$, $1.5 \mathrm{H}), 2.76(\mathrm{~s}, 2.2 \mathrm{H}), 2.75(\mathrm{~s}, 0.8 \mathrm{H}), 2.18(\mathrm{~s}, 2 \mathrm{H}), 2.17(\mathrm{~s}, 1 \mathrm{H})$, 2.14-1.96 (m, 6H), $1.93-1.86(\mathrm{~m}, 1 \mathrm{H}), 1.83-1.75(\mathrm{~m}, 1 \mathrm{H})$, $1.24(\mathrm{~s}, 3 \mathrm{H}), 1.07$ (s, 6H); ${ }^{13} \mathrm{C}$ NMR $\left(126 \mathrm{MHz}, \mathrm{CDCl}_{3}\right): \delta$ 206.4, 206.3, 170.2, 169.6, 168.8, 155.5, 154.7, 138.0, 137.3, 129.3, 128.9, 128.2, 128.1, 126.2, 126.1, 79.8, 79.5, 64.6, 60.2, 59.2, 58.1, 57.8, 56.3, 47.0, 46.9, 46.7, 46.4, 38.4, 34.3, 34.2, 29.9, 29.0, 28.2, 28.2, 28.1, 28.0, 27.7, 27.4, 27.4, 27.3, 27.2; IR (neat): $\nu_{\max } 2969,2876,1739,1686,1646,1535,1511,1437$, $1389,1367,1202,1147,868,772 \mathrm{~cm}^{-1}$; HRMS (ESI) calcd for $\mathrm{C}_{26} \mathrm{H}_{38} \mathrm{~N}_{3} \mathrm{O}_{5}[\mathrm{M}+\mathrm{H}]^{+}$: 472.2806; found, 472.2824.

5.16. Tetramer 8. To a stirred solution of trimer 23 (250 $\mathrm{mg}, 0.553 \mathrm{mmol})$ in $\mathrm{CH}_{2} \mathrm{Cl}_{2}(5 \mathrm{~mL})$ was added TFA $(0.12 \mathrm{~mL}$, $1.48 \mathrm{mmol})$, and the reaction mixture was stirred at $0{ }^{\circ} \mathrm{C}$ for 1 $\mathrm{h}$ and at $\mathrm{rt}$ for $1 \mathrm{~h}$. After completion of the reaction, benzene ( 5 $\mathrm{mL}$ ) was added to the reaction mixture and concentrated. After repetition of this operation five times, the trifluoroacetate salt of deprotected 23 was afforded and used in the next reaction without purification. To a $25 \mathrm{~mL}$ RB flask, triflouroacetate salt of deprotected 23, dry DMF and dry DIPEA (0.4 mL, 2.2 $\mathrm{mmol})$ were added at $\mathrm{rt}$; to this, acid $N$-Boc-L-Val $(153 \mathrm{mg}$, $0.66 \mathrm{mmol}$ ) in dry DMF (3 mL) was added. The suspension was stirred for $10 \mathrm{~min}$, and HATU ( $315 \mathrm{mg}, 0.82 \mathrm{mmol}$ ) was added under $\mathrm{N}_{2}$ atmosphere. After stirring for $12 \mathrm{~h}$, the reaction mixture was diluted with EtOAc and washed with $10 \%$ aq citric acid $(20 \mathrm{~mL})$ and sat. $\mathrm{NaHCO}_{3}(20 \mathrm{~mL})$. The organic layer was washed with brine, dried over $\mathrm{Na}_{2} \mathrm{SO}_{4}$, and concentrated. The residue was purified by column chromatography on silica gel (80\% EtOAc in hexane) to give the tetramer 8 (173 mg, 56\%) as a colorless oil; $[\alpha]_{\mathrm{D}}^{20}-136.20\left(c=0.55, \mathrm{CHCl}_{3}\right)$; mixture of rotamers, (2:1), ${ }^{1} \mathrm{H}$ NMR $\left(500 \mathrm{MHz}, \mathrm{CDCl}_{3}\right): \delta 7.25-7.20(\mathrm{~m}$, $2 \mathrm{H}), 7.19-7.12(\mathrm{~m}, 3 \mathrm{H}), 5.80(\mathrm{dd}, J=11.1,4.5 \mathrm{~Hz}, 1 \mathrm{H}), 4.69$ (dd, $J=8.6,4.5 \mathrm{~Hz}, 2 \mathrm{H}), 4.54(\mathrm{~d}, J=10.7 \mathrm{~Hz}, 0.6 \mathrm{H}), 4.30$ (d, $J$ $=10.4 \mathrm{~Hz}, 0.4 \mathrm{H}), 3.89-3.79(\mathrm{~m}, 1 \mathrm{H}), 3.78-3.69(\mathrm{~m}, 1.3 \mathrm{H})$, $3.68-3.56(\mathrm{~m}, 1.7 \mathrm{H}), 3.20-3.06(\mathrm{~m}, 2 \mathrm{H}), 3.05(\mathrm{~s}, 1 \mathrm{H}), 3.04(\mathrm{~s}$, $2 \mathrm{H}), 2.20$ (s, 3H), 2.19-2.12 (m, 4H), $2.04(\mathrm{~s}, 3 \mathrm{H}), 2.02-1.96$ $(\mathrm{m}, 2 \mathrm{H}), 1.96-1.86(\mathrm{~m}, 1.6 \mathrm{H}), 1.86-1.77(\mathrm{~m}, 1.4 \mathrm{H}), 1.42(\mathrm{~s}$, $6 \mathrm{H}), 1.41(\mathrm{~s}, 3 \mathrm{H}), 0.803-0.78(\mathrm{~m}, 3 \mathrm{H}), 0.77-0.73(\mathrm{~m}, 3 \mathrm{H})$; ${ }^{13} \mathrm{C}$ NMR (75 MHz, $\left.\mathrm{CDCl}_{3}\right): \delta 206.4,170.6,170.3,169.1$, $155.8,137.1,136.6,129.1,128.8,128.5,128.3,126.7,126.4$, $80.0,79.6,64.7,61.3,59.7,58.0,54.7,47.4,46.8,34.5,30.7$, $28.3,27.5,27.4,26.8,24.9,24.8,20.1,19.7,18.1,17.7$; IR (neat): $\nu_{\max }, 2970,2839,1716,1684,1657,1611,1605,1452$, $1325,1238,1165,1032,874, \mathrm{~cm}^{-1}$; HRMS (ESI) calcd for $\mathrm{C}_{32} \mathrm{H}_{48} \mathrm{~N}_{4} \mathrm{NaO}_{6}[\mathrm{M}+\mathrm{Na}]^{+}$: 607.3466; found, 607.3486.

5.17. Trimer 6. To a stirring solution of dimer 24 ( 2 g, 5.3 $\mathrm{mmol})$ in $\mathrm{MeOH} / \mathrm{H}_{2} \mathrm{O}(7: 3,15 \mathrm{~mL})$ was added $\mathrm{LiOH} \cdot \mathrm{H}_{2} \mathrm{O}$ $(0.6 \mathrm{~g}, 16.0 \mathrm{mmol})$, and the reaction mixture was stirred at $\mathrm{rt}$ for $3 \mathrm{~h}$. After that, the solvent $(\mathrm{MeOH})$ was removed in vacuo and the resulting mixture was acidified with $1 \mathrm{M} \mathrm{HCl}(20 \mathrm{~mL})$ to $\mathrm{pH} 4$ and extracted with EtOAc $(3 \times 30 \mathrm{~mL})$. The combined organic layer was washed with brine, dried over $\mathrm{Na}_{2} \mathrm{SO}_{4}$, and concentrated. The crude product was used in next step without further purification. To a stirred solution of Oep 20 (1.5 g, 7.0 $\mathrm{mmol})$ in $\mathrm{CH}_{2} \mathrm{Cl}_{2}(10 \mathrm{~mL})$ was added TFA $(1 \mathrm{~mL}, 13.1$ $\mathrm{mmol})$, and the reaction mixture was stirred at $0{ }^{\circ} \mathrm{C}$ for $1 \mathrm{~h}$ and at $\mathrm{rt}$ for $1 \mathrm{~h}$. After completion of the reaction, benzene $(10 \mathrm{~mL})$ was added to the reaction mixture and concentrated. After repetition of this operation five times, the trifluoroacetate salt of deprotected 20 was afforded and used in the next reaction without purification. To a $50 \mathrm{~mL}$ RB flask, triflouroacetate salt of deprotected 23, dry DMF $(10 \mathrm{~mL})$ and dry DIPEA (3.85 $\mathrm{mL}, 22.0 \mathrm{mmol}$ ) were added at $0{ }^{\circ} \mathrm{C}$. To this, $N$-Boc-L-Phe-Pro$\mathrm{OH}(2.0 \mathrm{~g}, 5.5 \mathrm{mmol})$ in dry DMF $(5 \mathrm{~mL})$ was added. The suspension was stirred for $10 \mathrm{~min}$, and HATU (2.51 g, 6.6 $\mathrm{mmol}$ ) was added under $\mathrm{N}_{2}$ atmosphere. After stirring for $12 \mathrm{~h}$, the reaction mixture was diluted with EtOAc and washed with $10 \%$ aq citric acid $(20 \mathrm{~mL})$ and sat. $\mathrm{NaHCO}_{3}(20 \mathrm{~mL})$. The organic layer was washed with brine, dried over $\mathrm{Na}_{2} \mathrm{SO}_{4}$, and concentrated. The residue was purified by column chromatography on silica gel (50\% EtOAc in hexane) to give trimer $6(1.8$ g, $72 \%)$ as a colorless oil; $[\alpha]_{\mathrm{D}}^{20}-20.73\left(c=1.15, \mathrm{CHCl}_{3}\right)$; mixture of rotamers $(5: 1),{ }^{1} \mathrm{H}$ NMR $\left(400 \mathrm{MHz}, \mathrm{CDCl}_{3}\right): \delta$ $7.33-7.13(\mathrm{~m}, 5 \mathrm{H}), 5.17(\mathrm{~d}, J=8.9 \mathrm{~Hz}, 0.6 \mathrm{H}), 4.80-4.61(\mathrm{~m}$, 2.4H), 3.94-3.81 (m, $1 \mathrm{H}), 3.78-3.67(\mathrm{~m}, 1 \mathrm{H}), 3.64-3.51(\mathrm{~m}$, $2 \mathrm{H}), 3.12(\mathrm{dd}, J=14.2,4.8 \mathrm{~Hz}, 1 \mathrm{H}), 2.85-2.77(\mathrm{~m}, 1 \mathrm{H}), 2.21$ (s, 3H), 2.19-2.12 (m, 2H), 2.09-1.93 (m, 4H), 1.93-1.77 $(\mathrm{m}, 2 \mathrm{H}), 1.43(\mathrm{~s}, 1.5 \mathrm{H}), 1.34(\mathrm{~s}, 7.5 \mathrm{H}) ;{ }^{13} \mathrm{C}$ NMR $(101 \mathrm{MHz}$, $\left.\mathrm{CDCl}_{3}\right): \delta 206.3,170.4,170.2,155.2,136.4,129.6,128.2,126.6$, 79.4, 64.8, 57.8, 52.9, 47.2, 46.9, 38.4, 28.4, 28.2, 27.6, 27.2, 24.9, 24.8; IR (neat): $\nu_{\max } 3432,2922,1709,1741,1497,1437$, 1362, 1253, 1216, 1164, 1089, 1021, 864, $799 \mathrm{~cm}^{-1}$; HRMS (ESI) calcd for $\mathrm{C}_{25} \mathrm{H}_{36} \mathrm{~N}_{3} \mathrm{O}_{5}[\mathrm{M}+\mathrm{H}]^{+}$: 458.2649; found, 458.2641.

5.18. N-Boc-L-Val-L-Val-L-Val-OMe (26). To a stirring solution of dimer $25(3.5 \mathrm{~g}, 9.1 \mathrm{mmol})$ in $\mathrm{MeOH} / \mathrm{H}_{2} \mathrm{O}(7: 3,50$ $\mathrm{mL}$ ) was added $\mathrm{LiOH} \cdot \mathrm{H}_{2} \mathrm{O}(1.2 \mathrm{~g}, 27.0 \mathrm{mmol})$, and the reaction mixture was stirred at $\mathrm{rt}$ for $3 \mathrm{~h}$. After that, the solvent 
$(\mathrm{MeOH})$ was removed in vacuo and the resulting mixture was acidified with $1 \mathrm{M} \mathrm{HCl}(20 \mathrm{~mL})$ to $\mathrm{pH} 4$ and extracted with EtOAc $(3 \times 30 \mathrm{~mL})$. The combined organic layer was washed with brine, dried over $\mathrm{Na}_{2} \mathrm{SO}_{4}$, and concentrated. The crude product was used in next step without further purification. To a stirred solution of L-valine methyl ester hydrochloride $(1.9 \mathrm{~g}$, $11.0 \mathrm{mmol})$ in dry $\mathrm{CH}_{2} \mathrm{Cl}_{2}(10 \mathrm{~mL})$ was added DIPEA $(5 \mathrm{~mL}$, $29.0 \mathrm{mmol}$ ) at $0{ }^{\circ} \mathrm{C}$ and stirred for $10 \mathrm{~min}$. The above crude product was dissolved in dry $\mathrm{CH}_{2} \mathrm{Cl}_{2}(25 \mathrm{~mL})$, and $\mathrm{EDC} \cdot \mathrm{HCl}$ ( $2.0 \mathrm{~g}, 10.4 \mathrm{mmol})$ and HOBt $(1.5 \mathrm{~g}, 10.4 \mathrm{mmol})$ were added to the above suspension; after stirring for $6 \mathrm{~h}$ at $\mathrm{rt}$, the reaction mixture was diluted with $\mathrm{CH}_{2} \mathrm{Cl}_{2}(50 \mathrm{~mL})$ and washed with $10 \%$ aq citric acid $(20 \mathrm{~mL})$ and sat. $\mathrm{NaHCO}_{3}(20 \mathrm{~mL})$. The organic layer was washed with brine, dried over $\mathrm{Na}_{2} \mathrm{SO}_{4}$, and concentrated. The residue was purified by column chromatography on silica gel (50\% EtOAc in hexane) to give the trimer $\mathbf{2 6}$ $(3.1 \mathrm{~g}, 75 \%)$ as a white solid; $\mathrm{mp} 156-158^{\circ} \mathrm{C}$; $[\alpha]_{\mathrm{D}}^{20}-33.69(c$ $\left.=1.65, \mathrm{CHCl}_{3}\right) ;{ }^{1} \mathrm{H} \mathrm{NMR}\left(300 \mathrm{MHz}, \mathrm{CDCl}_{3}\right): \delta 7.06(\mathrm{~s}, 1 \mathrm{H})$, $6.88(\mathrm{~s}, 1 \mathrm{H}), 5.44(\mathrm{~s}, 1 \mathrm{H}), 4.52(\mathrm{dd}, J=8.7,5.3 \mathrm{~Hz}, 1 \mathrm{H}), 4.38$ $(\mathrm{t}, J=8.1 \mathrm{~Hz}, 1 \mathrm{H}), 3.95(\mathrm{t}, J=7.7 \mathrm{~Hz}, 1 \mathrm{H}), 3.71(\mathrm{~s}, 3 \mathrm{H}), 2.22-$ $1.95(\mathrm{~m}, 3 \mathrm{H}), 1.41(\mathrm{~s}, 9 \mathrm{H}), 0.90(\mathrm{~s}, 9 \mathrm{H}), 0.87(\mathrm{~d}, J=9.9 \mathrm{~Hz}$, $9 \mathrm{H}) ;{ }^{13} \mathrm{C}$ NMR $\left(126 \mathrm{MHz}, \mathrm{CDCl}_{3}\right): \delta 172.1,172.0,171.3$, $155.9,79.6,60.2$, 58.6, 57.1, 52.0, 30.9, 30.8, 30.7, 28.3, 19.2, 19.1, 18.9, 18.3, 18.1, 17.8; IR (neat): $\nu_{\max } 3294,2964,2925$, $1739,1691,1644,1519,1462,1369,1299,1214,1166,1090$, 1016, 926, $875 \mathrm{~cm}^{-1}$; HRMS (ESI) calcd for $\mathrm{C}_{21} \mathrm{H}_{39} \mathrm{~N}_{3} \mathrm{NaO}_{6}$ $[\mathrm{M}+\mathrm{Na}]^{+}:$452.2731; found, 452.2733.

5.19. N-Boc-L-Ala-L-Pro-L-Val-L-Val-L-Val-OMe (5). To a stirred solution of trimer $26(2.0 \mathrm{~g}, 4.2 \mathrm{mmol})$ in $\mathrm{CH}_{2} \mathrm{Cl}_{2}(15$ $\mathrm{mL})$ was added TFA $(0.9 \mathrm{~mL}, 11.8 \mathrm{mmol})$, and the reaction mixture was stirred at $0{ }^{\circ} \mathrm{C}$ for $1 \mathrm{~h}$ and at rt for $1 \mathrm{~h}$. After completion of the reaction, benzene $(10 \mathrm{~mL})$ was added to the reaction mixture and concentrated. After repetition of this operation five times, the trifluoroacetate salt of deprotected 26 was afforded and used in the next reaction without purification. To a $25 \mathrm{~mL} \mathrm{RB}$ flask, triflouroacetate salt of deprotected 26, dry DMF $(10 \mathrm{~mL})$, and dry DIPEA $(2.6 \mathrm{~mL}, 15.0 \mathrm{mmol})$ were added at rt. To this, N-Boc-L-Ala-Pro-OH 27 (1.0 g, $3.7 \mathrm{mmol})$ in dry DMF $(5 \mathrm{~mL})$ was added. The suspension was stirred for $10 \mathrm{~min}$, and HATU (1.7 g, $4.5 \mathrm{mmol}$ ) was added under $\mathrm{N}_{2}$ atmosphere. After stirring for $12 \mathrm{~h}$, the reaction mixture was diluted with EtOAc and washed with $10 \%$ aq citric acid (20 $\mathrm{mL})$ and sat. $\mathrm{NaHCO}_{3}(20 \mathrm{~mL})$. The organic layer was washed with brine, dried over $\mathrm{Na}_{2} \mathrm{SO}_{4}$, and concentrated. The residue was purified by column chromatography on silica gel (50\% EtOAc in hexane) to give pentamer $5(1.3 \mathrm{~g}, 64 \%)$ as a white solid; $\mathrm{mp}=167-169{ }^{\circ} \mathrm{C}$; $[\alpha]_{\mathrm{D}}^{20}-84.15\left(c=0.8, \mathrm{CHCl}_{3}\right) ;{ }^{1} \mathrm{H}$ NMR (500 MHz, $\left.\mathrm{CDCl}_{3}\right): \delta 7.47(\mathrm{~s}, 1 \mathrm{H}), 6.92(\mathrm{~d}, J=33.7 \mathrm{~Hz}$, $1 \mathrm{H}), 6.78(\mathrm{~d}, J=18.3 \mathrm{~Hz}, 1 \mathrm{H}), 5.50(\mathrm{~d}, J=7.3 \mathrm{~Hz}, 1 \mathrm{H}), 4.68$ $(\mathrm{d}, J=5.2 \mathrm{~Hz}, 1 \mathrm{H}), 4.55-4.46(\mathrm{~m}, 2 \mathrm{H}), 4.41-4.33(\mathrm{~m}, 1 \mathrm{H})$, 4.32-4.23 (m, 1H), $3.72(\mathrm{~s}, 3 \mathrm{H}), 3.71-3.67(\mathrm{~m}, 1 \mathrm{H}), 3.61-$ $3.55(\mathrm{~m}, 1 \mathrm{H}), 2.21-2.06(\mathrm{~m}, 4 \mathrm{H}), 2.04-1.88(\mathrm{~m}, 3 \mathrm{H}), 1.41(\mathrm{~s}$, 9H), 1.31 (d, $J=7.3, \mathrm{~Hz}, 3 \mathrm{H}), 0.93(\mathrm{~d}, J=3.9 \mathrm{~Hz}, 3 \mathrm{H}), 0.91$ $(\mathrm{d}, J=3.5 \mathrm{~Hz}, 3 \mathrm{H}), 0.90(\mathrm{~d}, J=4.0 \mathrm{~Hz}, 3 \mathrm{H}), 0.89-0.87(\mathrm{~m}$, $6 \mathrm{H}), 0.87(\mathrm{~d}, J=2.0 \mathrm{~Hz}, 3 \mathrm{H}) ;{ }^{13} \mathrm{C} \mathrm{NMR}\left(126 \mathrm{MHz} \mathrm{CDCl}_{3}\right): \delta$ 173.1, 172.1, 171.3, 171.2, 171.0, 155.2, 79.7, 59.9, 58.9, 58.7, 57.1, 52.1, 47.8, 47.3, 31.0, 30.7, 30.5, 28.3, 27.5, 25.2, 19.3, 19.2, 18.9, 18.7, 18.2, 17.8, 17.7; IR (neat): $\nu_{\max } 3289,3074$, 2962, 2923, 1740, 1703, 1640, 1544, 1452, 1370, 1211, 1165, 1093, 1057, 1022, 924, 864, $754 \mathrm{~cm}^{-1}$; HRMS (ESI) calcd for $\mathrm{C}_{29} \mathrm{H}_{51} \mathrm{~N}_{5} \mathrm{NaO}_{8}[\mathrm{M}+\mathrm{Na}]^{+}$: 620.3630; found, 620.3614 .

5.20. Octapeptide 3a. To a stirring solution of pentamer 5 $(1 \mathrm{~g}, 1.6 \mathrm{mmol})$ in $\mathrm{MeOH} / \mathrm{H}_{2} \mathrm{O}(7: 3,10 \mathrm{~mL})$ was added
$\mathrm{LiOH} \cdot \mathrm{H}_{2} \mathrm{O}(211 \mathrm{mg}, 5.0 \mathrm{mmol})$, and the reaction mixture was stirred at rt for $3 \mathrm{~h}$. After that, the solvent $(\mathrm{MeOH})$ was removed in vacuo and the resulting mixture was acidified with 1 $\mathrm{M} \mathrm{HCl}(20 \mathrm{~mL})$ to $\mathrm{pH} 4$ and extracted with EtOAc $(3 \times 30$ $\mathrm{mL})$. The combined organic layer was washed with brine, dried over $\mathrm{Na}_{2} \mathrm{SO}_{4}$, and concentrated. The crude product was used in next step without further purification.

To a stirred solution of trimer $6(1.0 \mathrm{~g}, 2.1 \mathrm{mmol})$ in $\mathrm{CH}_{2} \mathrm{Cl}_{2}$ $(10 \mathrm{~mL})$ was added TFA $(0.3 \mathrm{~mL}, 4.3 \mathrm{mmol})$, and the reaction mixture was stirred at $0{ }^{\circ} \mathrm{C}$ for $1 \mathrm{~h}$ and at rt for $1 \mathrm{~h}$. After completion of the reaction, benzene $(10 \mathrm{~mL})$ was added to the reaction mixture and concentrated. After repetition of this operation five times, the trifluoroacetate salt of deprotected 6 was afforded and used in the next reaction without purification. To a $50 \mathrm{~mL}$ RB flask, triflouroacetate salt of deprotected 6, dry DMF $(5 \mathrm{~mL})$, and dry DIPEA $(1.19 \mathrm{~mL}, 6.8 \mathrm{mmol})$ were added at rt. To this, pentamer acid $(1.0 \mathrm{~g}, 1.7 \mathrm{mmol})$ in dry DMF ( $5 \mathrm{~mL}$ ) was added. The suspension was stirred for 10 min, and HATU (782 $\mathrm{mg}, 2.0 \mathrm{mmol}$ ) was added under $\mathrm{N}_{2}$ atmosphere. After stirring for $12 \mathrm{~h}$, the reaction mixture was diluted with EtOAc and washed with $10 \%$ aq citric acid (20 $\mathrm{mL})$ and sat. $\mathrm{NaHCO}_{3}(20 \mathrm{~mL})$. The organic layer was washed with brine, dried over $\mathrm{Na}_{2} \mathrm{SO}_{4}$, and concentrated. The residue was purified by column chromatography on silica gel ( $80 \%$ EtOAc in hexane) to give octapeptide $3 \mathrm{a}(822 \mathrm{mg}, 52 \%)$ as a white solid; $\mathrm{mp}=196-198{ }^{\circ} \mathrm{C} ;[\alpha]_{\mathrm{D}}^{20}-67.0\left(c=0.3, \mathrm{CHCl}_{3}\right)$; ${ }^{1} \mathrm{H} \mathrm{NMR}\left(500 \mathrm{MHz}, \mathrm{CDCl}_{3}\right.$ ): $\delta 7.60$ (br s, $\left.1 \mathrm{H}\right), 7.29$ (d, $J=7.3$ $\mathrm{Hz}, 1 \mathrm{H}), 7.24$ (d, J = 7.9 Hz, 1H), 7.22-7.13 (m, 5H), 6.89 (br s, $1 \mathrm{H}), 5.47($ br s, $1 \mathrm{H}), 5.07-4.97(\mathrm{~m}, 1 \mathrm{H}), 4.75-4.69(\mathrm{~m}$, $1 \mathrm{H}), 4.65(\mathrm{dd}, J=8.6,4.5 \mathrm{~Hz}, 1 \mathrm{H}), 4.52(\mathrm{~d}, J=7.4 \mathrm{~Hz}, 1 \mathrm{H})$, $4.45-4.20(\mathrm{~m}, 4 \mathrm{H}), 3.88-3.69(\mathrm{~m}, 3 \mathrm{H}), 3.65-3.51(\mathrm{~m}, 3 \mathrm{H})$, 3.17-3.06 (m, 1H), 2.93-2.84 (m, 1H), $2.20(\mathrm{~s}, 3 \mathrm{H}), 2.17-$ $2.10(\mathrm{~m}, 5 \mathrm{H}), 2.08-1.94(\mathrm{~m}, 8 \mathrm{H}), 1.83-1.72(\mathrm{~m}, 2 \mathrm{H}), 1.43(\mathrm{~s}$, $9 \mathrm{H}), 1.34(\mathrm{~d}, J=6.5 \mathrm{~Hz}, 3 \mathrm{H}), 0.93-0.79(\mathrm{~m}, 18 \mathrm{H}) ;{ }^{13} \mathrm{C} \mathrm{NMR}$ $\left(101 \mathrm{MHz} \mathrm{CDCl}_{3}\right): \delta 206.4,173.0,172.5,171.6,171.5,170.8$, $170.7,170.2$, 155.2, 136.2, 129.8, 129.5, 128.3, 126.6, 79.7, 66.1, 64.9, 60.1, 58.0, 57.9, 51.8, 51.6, 47.9, 47.4, 46.9, 37.9, 31.2, $30.7,30.7,29.7,28.4,27.6,27.2,25.2,24.9,19.4,19.3,18.7$, 18.6, 18.5, 18.2; IR (neat): $\nu_{\max } 3295,3078,2916,2901,1752$, $1703,1641,1547,1452,1375,1211,1165,1098,1057,1027$, 924, 867, $754 \mathrm{~cm}^{-1}$; HRMS (ESI) calcd for $\mathrm{C}_{48} \mathrm{H}_{74} \mathrm{~N}_{8} \mathrm{NaO}_{10}$ $[\mathrm{M}+\mathrm{Na}]^{+}$: 945.5420; found, 945.5437.

5.21. Desmethyl Jahanyne 1a. To a stirred solution of octapeptide $3 \mathrm{a}(200 \mathrm{mg}, 0.2 \mathrm{mmol})$, in $\mathrm{CH}_{2} \mathrm{Cl}_{2}(2 \mathrm{~mL})$ was added TFA $(0.03 \mathrm{~mL}, 0.4 \mathrm{mmol})$, and the reaction solution was stirred at $0{ }^{\circ} \mathrm{C}$ for $1 \mathrm{~h}$ and at $\mathrm{rt}$ for $1 \mathrm{~h}$. After completion of the reaction, benzene $(1 \mathrm{~mL})$ was added to the reaction mixture and concentrated. After repetition of this operation five times, the triflouroacetate salt of deprotected 24 was afforded and used in the next reaction without purification. To a $10 \mathrm{~mL} \mathrm{RB}$ flask, triflouroacetate salt of deprotected 3a, dry DMF, and dry DIPEA $(0.12 \mathrm{~mL}, 0.7 \mathrm{mmol})$ were added at rt. To this, acid 2 $(35 \mathrm{mg}, 0.17 \mathrm{mmol})$ in dry DMF $(3 \mathrm{~mL})$ was added. The suspension was stirred for $10 \mathrm{~min}$, and HATU $(79 \mathrm{mg}, 0.21$ $\mathrm{mmol}$ ) was added under $\mathrm{N}_{2}$ atmosphere. After stirring for $12 \mathrm{~h}$, the reaction mixture was diluted with EtOAc and washed with $10 \%$ aq citric acid $(5 \mathrm{~mL})$ and sat. $\mathrm{NaHCO}_{3}(5 \mathrm{~mL})$. The organic layer was washed with brine, dried over $\mathrm{Na}_{2} \mathrm{SO}_{4}$, and concentrated. The residue was purified by column chromatography on silica gel $\left(6 \% \mathrm{CHCl}_{3}\right.$ in $\left.\mathrm{MeOH}\right)$ followed by HPLC [Luna C8 $(250 \times 4.6 \mathrm{~mm}, 5.0 \mu \mathrm{m})$; flow rate $1.0 \mathrm{~mL} / \mathrm{min}$; detection, UV $210 \mathrm{~nm}$; solvent; $70 \% \mathrm{CH}_{3} \mathrm{CN}$ in $0.1 \%$ formic acid] give the desmethyl jahanyne 1a (78 mg, 44\%) yellow 
solid; $\mathrm{mp}=178-180{ }^{\circ} \mathrm{C}$; $[\alpha]_{\mathrm{D}}^{20}-50.80\left(c=1.25, \mathrm{CHCl}_{3}\right) ;{ }^{1} \mathrm{H}$ NMR (500 MHz, $\left.\mathrm{CDCl}_{3}\right): \delta 7.33-7.13(\mathrm{~m}, 5 \mathrm{H}), 7.03(\mathrm{br} \mathrm{s}$ $1 \mathrm{H}), 6.97-6.78(\mathrm{~m}, 1 \mathrm{H}), 6.72-6.58(\mathrm{~m}, 1 \mathrm{H}), 5.02-4.87(\mathrm{~m}$, $1 \mathrm{H}), 4.84-4.70(\mathrm{~m}, 1 \mathrm{H}), 4.66(\mathrm{dt}, J=10.6,5.2 \mathrm{~Hz}, 1 \mathrm{H}), 4.61-$ $4.55(\mathrm{~m}, 1 \mathrm{H}), 4.53-4.29(\mathrm{~m}, 2 \mathrm{H}), 4.28-3.99(\mathrm{~m}, 2 \mathrm{H}), 3.98-$ $3.52(\mathrm{~m}, 5 \mathrm{H}), 3.49-2.81(\mathrm{~m}, 3 \mathrm{H}), 2.36-2.21(\mathrm{~m}, 3 \mathrm{H}), 2.20(\mathrm{~s}$, $3 \mathrm{H}), 2.18-2.09(\mathrm{~m}, 6 \mathrm{H}), 2.09-2.03(\mathrm{~m}, 3 \mathrm{H}), 2.02-1.95(\mathrm{~m}$, $4 \mathrm{H}), 1.94(\mathrm{t}, J=2.8 \mathrm{~Hz}, 1 \mathrm{H}), 1.92-1.78(\mathrm{~m}, 2 \mathrm{H}), 1.53-1.38$ (m, $5 \mathrm{H}), 1.37-1.24(\mathrm{~m}, 6 \mathrm{H}), 1.17-1.09(\mathrm{~m}, 1 \mathrm{H}), 1.06(\mathrm{~d}, J=$ $6.5 \mathrm{~Hz}, 3 \mathrm{H}), 1.04-0.76(\mathrm{~m}, 18 \mathrm{H}), 0.74(\mathrm{~d}, J=6.7 \mathrm{~Hz}, 1.8 \mathrm{H})$, $0.67(\mathrm{~d}, J=6.7 \mathrm{~Hz}, 1.2 \mathrm{H}) ;{ }^{13} \mathrm{C} \mathrm{NMR}\left(101 \mathrm{MHz}, \mathrm{CDCl}_{3}\right): \delta$ 206.2, 176.4, 174.0, 172.8, 171.2, 170.6, 170.3, 170.0, 169.9, $136.3,129.4,129.2,128.4,126.8,84.6,68.2,64.9,60.2,59.7$, 58.3, 58.0, 51.9, 47.4, 46.9, 46.4, 41.3, 38.8, 38.7, 38.0, 37.9, $37.0,36.4,31.1,31.0,30.4,28.6,28.3,27.5,27.2,26.0,25.2$, 25.0, 24.8, 20.7, 19.4, 19.3, 19.2, 18.5, 18.4, 18.0, 17.7, 17.5, 17.4; IR (neat): $\nu_{\max } 3280,2960,2922,1720,1632,1533,1445$, 1437, 1375, 1217, 1160, 1096, 919, 801, $752 \mathrm{~cm}^{-1}$; HRMS (ESI) calcd for $\mathrm{C}_{55} \mathrm{H}_{84} \mathrm{~N}_{8} \mathrm{NaO}_{9}[\mathrm{M}+\mathrm{Na}]^{+}$: 1023.6253; found, 1023.6273 .

5.22. Compound 28. To a stirred solution of tetramer 7 (50 mg, $0.09 \mathrm{mmol})$, in $\mathrm{CH}_{2} \mathrm{Cl}_{2}(2 \mathrm{~mL})$ was added TFA $(0.2$ $\mathrm{mL}, 0.25 \mathrm{mmol}$ ), and the reaction solution was stirred at $0{ }^{\circ} \mathrm{C}$ for $1 \mathrm{~h}$ and at $\mathrm{rt}$ for $1 \mathrm{~h}$. After completion of the reaction, benzene $(1 \mathrm{~mL})$ was added to the reaction mixture and concentrated. After repetition of this operation five times, the triflouroacetate salt of deprotected 2 was afforded which was used in the next reaction without purification. To a $10 \mathrm{~mL} \mathrm{RB}$ flask, triflouroacetate salt of deprotected 19, dry DMF, and dry DIPEA $(0.6 \mathrm{~mL}, 0.37 \mathrm{mmol})$ were added at rt. To this, acid 2 $(21 \mathrm{mg}, 0.11 \mathrm{mmol})$ in dry $\operatorname{DMF}(3 \mathrm{~mL})$ was added. The suspension was stirred for $10 \mathrm{~min}$, and HATU $(52.7 \mathrm{mg}, 0.13$ mmol) was added under $\mathrm{N}_{2}$ atmosphere. After stirring for $12 \mathrm{~h}$, the reaction mixture was diluted with EtOAc and washed with $10 \%$ aq citric acid $(5 \mathrm{~mL})$ and sat. $\mathrm{NaHCO}_{3}(5 \mathrm{~mL})$. The organic layer was washed with brine, dried over $\mathrm{Na}_{2} \mathrm{SO}_{4}$, and concentrated. The residue was purified by column chromatography on silica gel (70\% EtOAc in hexane) followed by HPLC [CSH XSelect $(150 \times 4.6 \mathrm{~mm}, 5.0 \mu \mathrm{m})$; flow rate $1.0 \mathrm{~mL} / \mathrm{min}$; detection, UV $210 \mathrm{~nm}$; solvent; $75 \% \mathrm{CH}_{3} \mathrm{OH}$ in $0.1 \%$ formic acid] gave $28(23.8 \mathrm{mg}, 42 \%)$ as colorless liquid; $[\alpha]_{\mathrm{D}}^{20}-136.30$ $\left(c=0.3, \mathrm{CHCl}_{3}\right)$; mixture of rotamers, $(4: 1),{ }^{1} \mathrm{H}$ NMR (400 $\left.\mathrm{MHz}, \mathrm{CDCl}_{3}\right): \delta 5.51-5.44(\mathrm{~m}, 1 \mathrm{H}), 5.14(\mathrm{~d}, J=10.9 \mathrm{~Hz}$, $0.8 \mathrm{H}), 5.06(\mathrm{~d}, J=10.6 \mathrm{~Hz}, 0.2 \mathrm{H}), 4.85(\mathrm{~d}, J=10.6 \mathrm{~Hz}, 1 \mathrm{H})$, $4.80(\mathrm{dd}, J=7.9,3.6 \mathrm{~Hz}, 0.8 \mathrm{H}), 4.39(\mathrm{~d}, J=9.9 \mathrm{~Hz}, 0.2 \mathrm{H})$, $3.75-3.59(\mathrm{~m}, 2 \mathrm{H}), 3.69(\mathrm{~s}, 2.3 \mathrm{H}), 3.67(\mathrm{~s}, 0.7 \mathrm{H}), 3.09(\mathrm{~s}$, $2.2 \mathrm{H}), 3.05(\mathrm{~s}, 0.8 \mathrm{H}), 3.03(\mathrm{~s}, 2.3 \mathrm{H}), 3.01(\mathrm{~s}, 2.2 \mathrm{H}), 3.01(\mathrm{~s}$, $0.7 \mathrm{H}), 2.86-2.78(\mathrm{~m}, 1 \mathrm{H}), 2.77(\mathrm{~s}, 0.8 \mathrm{H}), 2.43-2.20(\mathrm{~m}, 2 \mathrm{H})$, $2.17(\mathrm{td}, J=6.9,2.6 \mathrm{~Hz}, 2 \mathrm{H}), 2.14-1.98(\mathrm{~m}, 2 \mathrm{H}), 1.93(\mathrm{t}, J=$ $2.7 \mathrm{~Hz}, 1 \mathrm{H}), 1.91-1.86(\mathrm{~m}, 1 \mathrm{H}), 1.75-1.68(\mathrm{~m}, 1 \mathrm{H}), 1.52-$ $1.35(\mathrm{~m}, 7 \mathrm{H}), 1.29(\mathrm{~d}, J=7.0 \mathrm{~Hz}, 3 \mathrm{H}), 1.27-1.24(\mathrm{~m}, 2 \mathrm{H})$, $1.08(\mathrm{~d}, J=6.7 \mathrm{~Hz}, 3 \mathrm{H}), 1.05(\mathrm{~d}, J=6.5 \mathrm{~Hz}, 0.8 \mathrm{H}), 1.01(\mathrm{~d}, J=$ $6.5 \mathrm{~Hz}, 2.2 \mathrm{H}), 0.93(\mathrm{~d}, J=6.7 \mathrm{~Hz}, 3 \mathrm{H}), 0.90(\mathrm{~d}, J=6.5 \mathrm{~Hz}$, $3 \mathrm{H}), 0.86(\mathrm{~d}, J=5.6 \mathrm{~Hz}, 3 \mathrm{H}), 0.76(\mathrm{~d}, J=6.7 \mathrm{~Hz}, 3 \mathrm{H}) ;{ }^{13} \mathrm{C}$ NMR $\left(75 \mathrm{MHz}, \mathrm{CDCl}_{3}\right): \delta 177.0,172.6,171.6,171.3,170.2$, $84.5,68.2,64.4,61.4,58.5,58.0,56.9,52.0,51.8,50.0,47.0$, 41.1, 40.9, 36.7, 33.5, 31.6, 30.5, 30.4, 30.2, 29.7, 28.6, 28.4, 27.4, 27.1, 26.0, 24.7, 19.9, 19.5, 19.1, 18.6, 18.3, 17.1, 14.2, 1.0; IR (neat): $\nu_{\max } 3325,1756,1673,1628,1624,2973,2876,2839$, $1740,1686,1651,1535,1442,1150,1081,868,771 \mathrm{~cm}^{-1}$; HRMS (ESI) calcd for $\mathrm{C}_{34} \mathrm{H}_{59} \mathrm{~N}_{4} \mathrm{O}_{6}[\mathrm{M}+\mathrm{H}]^{+}$: 619.4429; found, 619.4455 .
5.23. Compound 29. To a stirred solution of tetramer 8 (50 mg, $0.08 \mathrm{mmol})$, in $\mathrm{CH}_{2} \mathrm{Cl}_{2}(2 \mathrm{~mL})$ was added TFA (0.2 $\mathrm{mL}, 0.23 \mathrm{mmol})$, and the reaction solution was stirred at $0{ }^{\circ} \mathrm{C}$ for $1 \mathrm{~h}$ and at $\mathrm{rt}$ for $1 \mathrm{~h}$. After completion of the reaction, benzene $(1 \mathrm{~mL})$ was added to the reaction mixture and concentrated. After repetition of this operation five times, the triflouroacetate salt of deprotected $\mathbf{2 4}$ was afforded and used in the next reaction without purification. To a $10 \mathrm{~mL} \mathrm{RB}$ flask, triflouroacetate salt of deprotected 24, dry DMF, and dry DIPEA $(0.6 \mathrm{~mL}, 0.34 \mathrm{mmol})$ were added at rt. To this, acid 2 $(20 \mathrm{mg}, 0.1 \mathrm{mmol})$ in dry $\operatorname{DMF}(3 \mathrm{~mL})$ was added. The suspension was stirred for $10 \mathrm{~min}$, and HATU (48.4 mg, 0.12 mmol) was added under $\mathrm{N}_{2}$ atmosphere. After stirring for $12 \mathrm{~h}$, the reaction mixture was diluted with EtOAc and washed with $10 \%$ aq citric acid $(5 \mathrm{~mL})$ and sat. $\mathrm{NaHCO}_{3}(5 \mathrm{~mL})$. The organic layer was washed with brine, dried over $\mathrm{Na}_{2} \mathrm{SO}_{4}$, and concentrated. The residue was purified by column chromatography on silica gel ( $80 \%$ EtOAc in hexane) followed by HPLC [Luna C8 $(250 \times 4.6 \mathrm{~mm}, 5.0 \mu \mathrm{m})$; flow rate $1.0 \mathrm{~mL} / \mathrm{min}$; detection, UV $210 \mathrm{~nm}$; solvent; $70 \% \mathrm{CH}_{3} \mathrm{CN}$ in $0.1 \%$ formic acid] give the $29(36.8 \mathrm{mg}, 65 \%)$ as colorless liquid; $[\alpha]_{\mathrm{D}}^{20}$ $-185.65\left(c=1.35, \mathrm{CHCl}_{3}\right) ;{ }^{1} \mathrm{H}$ NMR $\left(500 \mathrm{MHz}, \mathrm{CDCl}_{3}\right): \delta$ $7.25-7.18(\mathrm{~m}, 2 \mathrm{H}), 7.17-7.12(\mathrm{~m}, 3 \mathrm{H}), 5.91-5.85(\mathrm{~m}, 1 \mathrm{H})$, $5.02(\mathrm{dd}, J=10.5,3.2 \mathrm{~Hz}, 1 \mathrm{H}), 4.73-4.59(\mathrm{~m}, 2 \mathrm{H}), 3.89-3.70$ $(\mathrm{m}, 2 \mathrm{H}), 3.67-3.54(\mathrm{~m}, 2 \mathrm{H}), 3.15-2.98(\mathrm{~m}, 2 \mathrm{H}), 2.93(\mathrm{~s}, 3 \mathrm{H})$, 2.54-2.43 (m, 1H), $2.17(\mathrm{~s}, 3 \mathrm{H}), 2.17-2.14(\mathrm{~m}, 3 \mathrm{H}), 2.13(\mathrm{~s}$, $3 \mathrm{H}), 2.12-1.92(\mathrm{~m}, 6 \mathrm{H}), 1.91-1.89(\mathrm{~m}, 1 \mathrm{H}), 1.88-1.75(\mathrm{~m}$, $2 \mathrm{H}), 1.47-1.35(\mathrm{~m}, 5 \mathrm{H}), 1.29-1.19(\mathrm{~m}, 3 \mathrm{H}), 1.07-1.00(\mathrm{~m}$, $1 \mathrm{H}), 0.93-0.88(\mathrm{~m}, 3 \mathrm{H}), 0.83-0.79(\mathrm{~m}, 6 \mathrm{H}), 0.68-0.64(\mathrm{~m}$, $3 \mathrm{H}) ;{ }^{13} \mathrm{C}$ NMR $\left(101 \mathrm{MHz}, \mathrm{CDCl}_{3}\right): \delta 206.4,176.4,170.3$, 170.2 , 168.9, 137.0, 129.1, 128.2, 126.4, 84.4, 68.1, 64.7, 58.0, 58.0, 54.2, 47.4, 46.8, 40.9, 36.3, 34.4, 33.2, 30.4, 30.1, 29.0, 28.6, 28.2, 27.4, 27.3, 26.6, 25.9, 24.8, 24.7, 19.8, 19.5, 18.3, 17.9, 17.1; IR (neat): $\nu_{\max } 3312,2958,2925,2835,1721,1691$, $1606,1443,1366,1165,751,700 \mathrm{~cm}^{-1}$; HRMS (ESI) calcd. for $\mathrm{C}_{39} \mathrm{H}_{58} \mathrm{~N}_{4} \mathrm{NaO}_{5}[\mathrm{M}+\mathrm{Na}]^{+}$: 685.4299; found, 685.4293.

\section{ASSOCIATED CONTENT}

\section{S Supporting Information}

The Supporting Information is available free of charge on the ACS Publications website at DOI: 10.1021/acsomega.7b01634.

${ }^{1} \mathrm{H},{ }^{13} \mathrm{C}$ NMR spectra, and cytotoxicity raw data for all products and docking data for compounds 28 and 29 (PDF)

\section{AUTHOR INFORMATION}

\section{Corresponding Author}

*E-mail: srivaric@iict.res.in (S.C.).

ORCID

Amitava Das: 0000-0002-7510-1805

Srivari Chandrasekhar: 0000-0003-3695-4343

\section{Author Contributions}

${ }^{\perp}$ S.K. and M.K. contributed equally to this work.

\section{Notes}

The authors declare no competing financial interest.

\section{ACKNOWLEDGMENTS}

The authors thank Council of Scientific and Industrial Research, Department of Science and Technology, and Department of Biotechnology, Government of India for research grants. The authors thank Dr. G. Nagendra and Dr. 
Rambabu Chegondi for scientific discussions and Y. Suresh in assisting flow cytometric analysis. We thank CSIR, New Delhi for financial support as part of the XII five-year programme project under ORIGIN (CSC-108) and SMiLE (CSC-0111). S.C. thanks DST for J. C. Bose fellowship (SB/S2/JCB-002/ 2015).

\section{REFERENCES}

(1) Blunt, J. W.; Copp, B. R.; Hu, W.-P.; Munro, M. H. G.; Northcote, P. T.; Prinsep, M. R. Marine natural products. Nat. Prod. Rep. 2009, 26, 170-244.

(2) Mi, Y.; Zhang, J.; He, S.; Yan, X. New Peptides Isolated from Marine Cyanobacteria, an Overview over the Past Decade. Mar. Drugs 2017, 15, 132.

(3) Iwasaki, A.; Ohno, O.; Sumimoto, S.; Ogawa, H.; Nguyen, K. A.; Suenaga, K. Jahanyne, an Apoptosis-Inducing Lipopeptide from the Marine Cyanobacterium Lyngbya sp. Org. Lett. 2015, 17, 652-655.

(4) Okamoto, S.; Iwasaki, A.; Ohno, O.; Suenaga, K. Isolation and Structure of Kurahyne B and Total Synthesis of the Kurahynes. J. Nat. Prod. 2015, 78, 2719-2725.

(5) Ogawa, H.; Iwasaki, A.; Sumimoto, S.; Kanamori, Y.; Ohno, O.; Iwatsuki, M.; Ishiyama, A.; Hokari, R.; Otoguro, K.; Ōmura, S.; Suenaga, K. Janadolide, a Cyclic Polyketide-Peptide Hybrid Possessing a tert-Butyl Group from an Okeania sp. Marine Cyanobacterium. J. Nat. Prod. 2016, 79, 1862-1866.

(6) Teruya, T.; Sasaki, H.; Fukazawa, H.; Suenaga, K. Bisebromoamide, a Potent Cytotoxic Peptide from the Marine Cyanobacterium Lyngbya sp.: Isolation, Stereostructure, and Biological Activity. Org. Lett. 2009, 11, 5062-5065.

(7) Hooper, G. J.; Orjala, J.; Schatzman, R. C.; Gerwick, W. H. Carmabins A and B, New Lipopeptides from the Caribbean Cyanobacterium Lyngbya majuscule. J. Nat. Prod. 1998, 61, 529-533.

(8) McPhail, K. L.; Correa, J.; Linington, R. G.; González, J.; OrtegaBarría, E.; Capson, T. L.; Gerwick, W. H. Antimalarial Linear Lipopeptides from a Panamanian Strain of the Marine Cyanobacterium Lyngbya majuscule. J. Nat. Prod. 2007, 70, 984-988.

(9) Czabotar, P. E.; Lessene, G.; Strasser, A.; Adams, J. M. Control of apoptosis by the BCL-2 protein family: implications for physiology and therapy. Nat. Rev. Mol. Cell Biol. 2014, 15, 49-63.

(10) Youle, R. J.; Strasser, A. The BCL-2 protein family: opposing activities that mediate cell death. Nat. Rev. Mol. Cell Biol. 2008, 9, 4759.

(11) Odinokov, V. N.; Ishmuratov, G. Y.; Kharisov, R. Y.; Yakovleva, M. P.; Sultanov, R. M.; Serebryakov, É. P.; Dzhemilev, U. M.; Tolstikov, G. A. Insect pheromones and their analogues. Chem. Nat. Compd. 1991, 27, 500-502.

(12) Liotta, R.; Brown, H. C. Hydroboration. 48. Effect of structure on selective monohydroboration of representative nonconjugated dienes by 9-borabicyclo[3.3.1] nonane. J. Org. Chem. 1977, 42, 28362839.

(13) Kumar, V. P.; Chandrasekhar, S. Enantioselective Synthesis of Pladienolide B and Truncated Analogues as New Anticancer Agents. Org. Lett. 2013, 15, 3610-3613.

(14) Kesenheimer, C.; Kalogerakis, A.; Meißner, A.; Groth, U. The Cobalt Way to Angucyclinones: Asymmetric Total Synthesis of the Antibiotics (+)-Rubiginone B2, (-)-Tetrangomycin, and (-)-8-OMethyltetrangomycin. Chem.-Eur. J. 2010, 16, 8805-8821.

(15) Magauer, T.; Martin, H. J.; Mulzer, J. Total Synthesis of the Antibiotic Kendomycin by Macrocyclization using Photo-Fries Rearrangement and Ring-Closing Metathesis. Angew. Chem., Int. Ed. 2009, 48, 6032-6036.

(16) Murthy, A. S.; Mahipal, B.; Chandrasekhar, S. Asymmetric Synthesis of the C14-C26 Building Block of Eribulin Mesylate. Eur. J. Org. Chem. 2012, 6959-6966.

(17) Sudhakar, G.; Reddy, K. J.; Nanubolu, J. B. Total synthesis of palmyrolide A and its 5,7-epi-isomers. Tetrahedron 2013, 69, 24192429.
(18) Moyes, C. R.; Berger, R.; Goble, S. D.; Harper, B.; Shen, D.-M.; Wang, L.; Bansal, A.; Brown, P. N.; Chen, A. S.; Dingley, K. H.; Di Salvo, J.; Fitzmaurice, A.; Gichuru, L. N.; Hurley, A. L.; Jochnowitz, N.; Miller, R. R.; Mistry, S.; Nagabukuro, H.; Salituro, G. M.; Sanfiz, A.; Stevenson, A. S.; Villa, K.; Zamlynny, B.; Struthers, M.; Weber, A. E.; Edmondson, S. D. Design, Synthesis, and Evaluation of Conformationally Restricted Acetanilides as Potent and Selective $\beta 3$ Adrenergic Receptor Agonists for the Treatment of Overactive Bladder. J. Med. Chem. 2014, 57, 1437-1453.

(19) Shin, C.-g.; Honda, S.; Morooka, K.; Yonezawa, Y. Dehydrooligopeptides. XIV. Convenient coupling of $n$-carboxy- $\alpha$ dehydroamino Acid Anhydride with both amine and carboxyl components. Bull. Chem. Soc. Jpn. 1993, 66, 1844-1846.

(20) Kong, C.; Jana, N.; Driver, T. G. Rh2(II)-Catalyzed Selective Aminomethylene Migration from Styryl Azides. Org. Lett. 2013, 15, 824-827.

(21) Cushman, M.; Oh, Y. I.; Copeland, T. D.; Oroszlan, S.; Snyder, $\mathrm{S}$. W. Development of methodology for the synthesis of stereochemically pure Phe.psi. $\left[\mathrm{CH}_{2} \mathrm{~N}\right]$ Pro linkages in HIV protease inhibitors. J. Org. Chem. 1991, 56, 4161-4167.

(22) Maeda, K.; Saito, H.; Osaka, K.; Nishikawa, K.; Sugie, M.; Morita, T.; Takahashi, I.; Yoshimi, Y. Direct modification of tripeptides using photoinduced decarboxylative radical reactions. Tetrahedron 2015, 71, 1117-1123.

(23) Olsen, R. k. Synthesis of Protected N-Methylamino Acid Derivatives. J. Org. Chem. 1970, 35, 1912-1915.

(24) Prashad, M.; Har, D.; Hu, B.; Kim, H.-Y.; Repic, O.; Blacklock, T. J. An Efficient and Practical N-Methylation of Amino Acid Derivatives. Org. Lett. 2003, 5, 125-128.

(25) Taleb, A. B.; Jenner, G. Scope of the $N$-alkylation of amides and the C-alkylation of malonates by methyl formate and dimethyl carbonate. J. Mol. Catal. 1993, 84, L131-L136.

(26) Kim, D. I.; Jeon, G. H.; Kim, S. J. Process for preparation of peptide derivatives. U.S. Patent WO 2,002,064,623 A1, 2002.

(27) Coupling between acid (or) acid chloride of $\mathbf{2 8}$ and free amine of 8 with coupling reagents such as HATU, COMU, PyBrop etc. did not give the jahanyne 1 .

(28) Geesala, R.; Gangasani, J. K.; Budde, M.; Balasubramanian, S.; Vaidya, J. R.; Das, A. 2-Azetidinones: Synthesis and biological evaluation as potential antibreast cancer agents. Eur. J. Med. Chem. 2016, 124, 544-558.

(29) Ramachandran, C.; You, W.; Krishan, A. Bcl-2 and mdr-1 gene expression during doxorubicin-induced apoptosis in murine leukemic P388 and P388/R84 cells. Anticancer Res. 1997, 17, 3369-3376.

(30) Yip, K. W.; Reed, J. C. Bcl-2 family proteins and cancer. Oncogene 2008, 27, 6398-6406.

(31) Adams, J. M.; Cory, S. The Bcl-2 apoptotic switch in cancer development and therapy. Oncogene 2007, 26, 1324-1337.

(32) Manupati, K.; Dhoke, N. R.; Debnath, T.; Yeeravalli, R.; Guguloth, K.; Saeidpour, S.; De, U. C.; Debnath, S.; Das, A. Inhibiting epidermal growth factor receptor signaling potentiates mesenchymalepithelial transition of breast cancer stem cells and their responsiveness to anticancer drugs. FEBS J. 2017, 284, 1830-1854.

(33) Jafari, R.; Almqvist, H.; Axelsson, H.; Ignatushchenko, M.; Lundbäck, T.; Nordlund, P.; Molina, D. M. The cellular thermal shift assay for evaluating drug target interactions in cells. Nat. Protoc. 2014, 9, 2100-2122.

(34) Cheung, S. T.; Benoiton, N. L. N-Methylamino acids in peptide synthesis $\mathrm{V}$. The synthesis of $\mathrm{N}$-tert-butyloxy carbonyl, $\mathrm{N}$-methylamino acids by $N$-methylation. Can. J. Chem. 1977, 55, 906-910.

(35) Lan, H.-Q.; Ye, J.-L.; Wang, A.-E.; Ruan, Y.-P.; Huang, P.-Q. A Flexible Asymmetric Approach to Methyl 5-Alkyltetramates and Its Application in the Synthesis of Cytotoxic Marine Natural Product Belamide A. Chem.-Eur. J. 2011, 17, 958-968.

(36) Boger, D. L.; Chen, J.-H.; Saionz, K. W. (-)-Sandramycin: Total Synthesis and Characterization of DNA Binding Properties. J. Am. Chem. Soc. 1996, 118, 1629-1644. 